\title{
Optimal Penalties on Deviations from Budgetary Targets
}

\author{
Séverine Menguy \\ Université Paris Descartes, Sorbonne Paris Cité, 12 Rue de l'École de Médecine, 75270 Paris Cedex 06, France \\ Correspondence should be addressed to Séverine Menguy; severine.menguy@orange.fr
}

Received 6 April 2014; Accepted 8 May 2014; Published 2 June 2014

Academic Editor: João Ricardo Faria

Copyright (C) 2014 Séverine Menguy. This is an open access article distributed under the Creative Commons Attribution License, which permits unrestricted use, distribution, and reproduction in any medium, provided the original work is properly cited.

\begin{abstract}
Beyond traditional arguments justifying the introduction of fiscal rules, this paper analyses their potential contribution to an indirect budgetary coordination between the member countries of a monetary union. Indeed, thanks to appropriate fiscal penalties, the noncooperative and decentralized equilibrium could get closer to the optimal equilibrium where the budgetary authorities cooperate. Our macroeconomic model shows that whatever penalty on the structural budgetary deficit would be optimal in case of asymmetric shocks. A moderate penalty on the excessive indebtedness level would be optimal in "normal times," or in case of asymmetric shocks if openness to trade and price flexibility are sufficiently high, whereas the share of public consumption in GDP, taxations rates, and indebtedness levels is sufficiently weak in the monetary union. Besides, in case of symmetric shocks, a fiscal penalty would be useful to decrease the excessive budgetary activism, even if it doesn't allow reaching the optimal and first-best equilibrium. Furthermore, the fiscal penalty should always be an increasing function of the share of public consumption in GDP and of taxation rates but a decreasing function of the strength of automatic stabilizers, of openness to trade, and of price flexibility in the member countries of the monetary union.
\end{abstract}

\section{Introduction}

Monetary unification creates new financial externalities, which seem to necessitate a stronger fiscal discipline in a monetary union in order to avoid that a member state had to suffer from the irresponsible fiscal behaviour of another member country. Indeed, in a monetary union, the fiscal laxity of a country can increase interest rates and endanger financial stability for all partner countries. It is precisely what is happening since 2010 in Europe in the framework of the sovereign debt crisis. As mentioned by Buti and Franco [1], monetary union membership can give rise to moral hazard problems: the fiscal discipline can be weakened if a fiscally lax country expects that the central bank or another country will bail it out. Besides, it can also imply a free riding behavior, which relies on the knowledge that a higher budgetary deficit would imply a smaller increase in average interest rates at the level of the whole monetary union. The drawback in terms of increase in the common interest rate will be more limited and spread between all member countries of the monetary union ("beggar thy neighbor" policy). Indeed, financial markets are not always sufficiently efficient in order to discipline budgetary policies and to perfectly evaluate the risk premiums related to the public debts of the various member countries of a monetary union. Moreover, fiscal discipline is often considered as the necessary condition to allow an independent common central bank to pursue its fundamental goal of price stability in a monetary union. Indeed, too high indebtedness levels imply a risk of monetization of these public debts, and thus a risk of rising inflation in the whole monetary union.

In the European Economic and Monetary Union (EMU), to limit these risks of moral hazard problems, the "no bailout" clause in the Maastricht Treaty excludes the possibility of a member state assuming liability for the sovereign debt of other member states. Nevertheless, the Greek situation since 2010 has proven the weak credibility of such a clause. Indeed, Lane [2] mentions that an effective market discipline requires that capital markets be open, that information on the borrower's existing liabilities be readily available, that no bailout be anticipated, and that the borrower responds to market signals. Regarding these conditions, financial markets are not perfect in Europe; in particular, the no-bailout clause of a member country with huge budgetary and indebtedness 
difficulties is simply not credible. The current sovereign debt crisis has proven that letting a member country of the EMU default is a solution which, in fact, all other member countries will try to avoid. Therefore, there are large externalities and interdependencies between the public debts of the member countries of a monetary union, which reduce the power of financial markets to discipline efficiently the fiscal policies of these countries' governments.

Therefore, in a monetary union, even if the last autonomous instrument in the hands of national governments, budgetary policies, must keep some independence in order to stabilize asymmetric cyclical variations, fiscal rules are necessary. A fiscal rule is a permanent constraint on fiscal policy through simple numerical limits on budgetary aggregates. So, since the creation of EMU, fiscal discipline has essentially consisted in such fiscal rules (Maastricht criteria, stability and growth pact, and fiscal compact) intended to limit budgetary deficits and public debts for the member countries. Fiscal rules aim at ensuring the longterm sustainability of public finances; they can concern the budgetary deficit or the public debt. They must also avoid the tendency to conduct excessively lax budgetary policies. However, beyond the arguments previously mentioned, fiscal rules can have another advantage. In the framework of largely decentralized and autonomous budgetary policies, as in the EMU, where budgetary policies are widely independent and decided at the national level, they can also contribute to a kind of budgetary coordination.

Indeed, the formal and explicit coordination between budgetary policies is quite minimal in Europe, in the framework of the European Council or of the Euro-group. So, the aim of the current paper is to justify the existence of fiscal rules and penalties by their contribution to an indirect coordination between the European budgetary authorities. We show that appropriate fiscal penalties can sometimes be a kind of substitute to a formal coordination of budgetary policies in a monetary union. Indeed, they can contribute to influence the noncooperative and decentralized budgetary equilibrium. Thanks to appropriate fiscal penalties, the decentralized equilibrium can then get closer to the optimal and first-best equilibrium where the budgetary authorities cooperate. Therefore, fiscal rules could compensate for the lack of willingness from the European governments to coordinate more formally and in a more binding way their budgetary and fiscal policies. Indeed, the optimal contract for a central bank has widely been studied, in the tradition of Walsh in particular. But the current paper analyses the optimal contract regarding the decentralized governments in a monetary union. It studies the usefulness of fiscal discipline and of fiscal rules associated with penalties in case of deviations from a given target. Can such fiscal penalties be a substitute to a formal coordination of budgetary policies in a monetary union and can they make the decentralized budgetary policies closer to the cooperative equilibrium?

The second section mentions the evolution of fiscal rules and penalties in the EMU, as well as some results in the economic literature on their usefulness and efficiency. The third section describes a simple macroeconomic model, where monetary policy is conducted by a common central bank, while decentralized budgetary policies are decided by the governments. The model also includes a penalty on the deviation of the budgetary deficit or the public debt from a given targeted value. In the following sections, the idea is to define the optimal fiscal penalties that could make the decentralized Nash equilibrium for the budgetary policies closer to an optimal and cooperative centralized budgetary equilibrium. The fourth section studies how to limit the structural budgetary deficit or how to make the public debt converge towards a targeted level. The fifth and sixth sections analyse, respectively, how to make the decentralized noncooperative budgetary policies answer in a more optimal way to the symmetric or to the asymmetric supply or demand shocks. The seventh section concludes the paper.

\section{Fiscal Penalties in the European Economic and Monetary Union}

\subsection{From the Stability and Growth Pact to the Fiscal Com-} pact. In 1992, article $104 \mathrm{c}$ of the Maastricht Treaty and the annexed Protocol 5 included thresholds and constraints on the global budgetary deficit (which had to be below $3 \%$ of GDP) and on the public debt (which had to be below $60 \%$ of GDP). Afterwards, in 1996, the stability and growth pact (SGP) added that national budgetary policies should "create room for maneuver in adapting to exceptional and cyclical disturbances," while avoiding excessive deficits. Hence, EMU member countries should have a mediumterm budgetary objective "close to balance or in surplus"; they should maintain a balanced budget over the economic cycle. This structural budgetary equilibrium should make enough room for maneuvering for automatic stabilizers to play and for economic stabilization in the short run in case of macroeconomic shocks.

After the reform of the SGP in 2005, there was more flexibility in the medium-term deficit target but also a more restrictive definition of the fiscal objective: it was clearly stated that the medium-term target should apply to the cyclically adjusted budget balance. Indeed, the primary budgetary deficit has two components: a structural part and a cyclical or conjunctural part. The conjunctural deficit is a decreasing function of the output gap, of the excess output in comparison with its potential value. On the opposite side, the structural deficit is the public deficit cleared of cyclical effects and one-off measures as well as temporary measures. In this framework, the main advantage of a shift to a structural deficit rule would be the increased flexibility in dealing with cyclical stabilization. On the other hand, the main difficulty relies naturally on the possibility to evaluate a structural deficit. Indeed, the operational simplicity of such an indicator is widely put into question given the reference to controversial magnitudes of the variables used in calculation, such as the output gap and the NAIRU.

Regarding the potential penalties imposed on the deviation of the budgetary deficit from its targeted value, in the framework of the excessive deficit procedure, sanctions could be applied if a given country did not take effective action to consider the council notification regarding the speed 
of correction of its excessive budgetary deficit. Sanctions consisted of a non-interest-bearing deposit combining a fixed element (equal to $0.2 \%$ of GDP) and a variable element, equal to one-tenth of the excess over the reference value, with a ceiling for the overall deposit of $0.5 \%$ of GDP. As long as the excessive deficit was not corrected, further deposits equal to one-tenth of the excess over the reference value (up to the aforementioned ceiling) would be required. After two years, deposits would be converted into fines.

However, the problem of the stability and growth pact relied on its lack of enforcement rules. After 2003, the deficit and debt rules were frequently broken without associated sanctions for the member states. Besides, the sovereign debt crisis has further contributed to underline the drawbacks of the European governance and, in particular, the lack of enforcement of fiscal rules in order to provide a sane fiscal framework in the EMU. That is why fiscal rules have been recently modified in the EMU.

On 29 September 2010, the European Commission proposed a revision of the stability and growth pact, a set of six legislative proposals aiming at strengthening the European economic governance (see, e.g. : European Commission [3] (see European Commission [3, pp. 61-100], for a discussion of the European framework and of the reform of the SGP with new rules giving more importance to the debt criterion) or ECB [4] for a complete description or Tamborini [5]). The $3 \%$ of GDP limit for budgetary deficits and the medium-term objective of budgetary positions in balance are maintained. But the so-called "six pack" has introduced a new set of rules for economic and fiscal surveillance in Europe.

(i) Countries will face sanctions if public spending increases more rapidly than GDP, unless this is compensated by a rise in taxation or if they run a budgetary surplus.

(ii) "The budgetary position of the general government of a contracting party shall be balanced or in surplus," that is "at its country-specific medium-term objective $[\cdots]$, with a lower limit of a structural deficit of $0.5 \%$ of the gross domestic product at market prices" (article 3(1) (a)). Countries in situation of excessive deficit will face sanctions if they do not cut their structural deficit by $0.5 \%$ per year.

(iii) Countries running a higher than $60 \%$ of GDP public debt ratio will be under an excessive deficit procedure (EDP) if this debt ratio does not fall by $1 / 20$ th per year of the gap between the effective debt and the $60 \%$ reference value (on average over 3 years). Nevertheless, given that most countries are today in EDP in the European Union and have to comply with agreed fiscal consolidation paths, they are granted a three-year period following the correction of the excessive deficit for meeting the debt rule.

(iv) Guilty countries (countries with too rapid rises in public spending, countries not cutting their structural deficit, or not complying with the measures associated with an EDP) will have to make a deposit of between $0.2 \%$ and $0.5 \%$ of GDP, which will possibly be converted into a fine if requested measures are not implemented.

(v) Countries are supposed to introduce European rules in their fiscal frameworks (the $3 \%$ and $60 \%$ limits, the medium-term target of budgetary positions in balance) and to implement a surveillance of these rules by an "independent budgetary institution." The member states have to introduce in their legislation a "balanced budget rules" limiting the structural budgetary deficit to $0.5 \%$ of GDP, as well as automatic correction mechanisms "in the event of significant observed deviations from the medium-term objective or the adjustment path towards it" (article 3(1) (e)). The EU Court of Justice will verify that it complies with European rules.

(vi) Countries will need a qualified majority at the European Council to oppose sanctions for countries breaching the $3 \%$ ceiling or not complying with instructions given by the Commission, this being expected to ensure the automaticity of sanctions ("reverse qualified majority voting") (article 7).

Therefore, the corrective part of the SGP has been strongly reinforced. Countries must submit each year a stability and convergence program (SCP) and reduce their budgetary deficits according to a schedule proposed by the Commission. Sanctions can now be imposed in case of deviations of the budgetary deficit or the public debt from a targeted value. This legislative package, the so-called "six pack," is the fiscal part of a new "treaty on stability, coordination, and governance (TSCG)," called the "fiscal compact," which entered into force on January 1st 2013, after ratification by 12 Euro area countries.

According to the fiscal compact, supranational rules must be introduced in the national constitutional or quasiconstitutional law; the European Court of Justice (ECJ) has the power to verify the enactment and the compliance of national laws with the new "golden rule" introduced in the fiscal compact. Besides, Fabbrini [6] mentions that the power of the ECJ could progressively be extended to the enforcement of the obligation of states to respect this "golden rule" in their budgetary procedures. So, according to the author, US states enjoy a high fiscal sovereignty vis-à-vis the federal government, in comparison with the direct interference that EU institutions have on the budgetary policy of the member states. They have established a regime for Eurozone governance that sacrifices state sovereignty much more than would have been permitted in a federal system. The fiscal compact's adoption may therefore lead to the paradoxical situation of making fiscal policy management in the EU supranational system much more centralized than in the U.S. federal one. This is ironic considering that $\mathrm{EU}$ member states have systematically discarded a federalist arrangement for the governance of the Eurozone as being incompatible with state sovereignty.

2.2. The Literature. The previous section has shown that fiscal rules associated with penalties in case of deviations 
from targeted values have been successively imposed on the European countries members of the EMU. Indeed, we have mentioned the explicit financial penalties that can be imposed on a given country in the framework of the fiscal compact. But there are also the costs that the markets may inflict as well as the loss of "political credibility" that could be involved. Indeed, sanctions can also consist in the loss of reputation and credibility due to excessive budgetary deficits. This loss of credibility itself can have a financial cost if the financial markets increase the interest rates on the public debt of a given country. Besides, a penalty on the excessive structural budgetary deficit (as mentioned in the fiscal compact) depends on two things. The first one is the possibility to precisely observe the level of the structural deficit and, therefore, to penalize the deviation in comparison with a very uncertain and subjective value. Output gaps are measured with delays and are subject to substantial revisions. The second one is the will of the legislator to effectively impose sanctions on countries which encounter difficulties, because such a decision will be in practice suboptimal, and so the enforceability of the rule can be questioned. In this context, the economic literature underlying the advantages or drawbacks of fiscal rules is very large. Therefore, we will only mention some useful results of this literature for the aim of our paper: analysing the contribution of fiscal rules to a kind of coordination between the budgetary authorities in the EMU.

Firstly, in the framework of the stability and growth pact, fiscal discipline was often blamed for being detrimental to economic stabilization by constraining budgetary policies of countries whose deficits where initially excessively high and by implying procyclical budgetary policies. That is why the stress was progressively put on reaching a structural balance in equilibrium in order to have enough flexibility to stabilize macroeconomic shocks. For example, Artis and Buti [7] underline the dangers of fiscal targets for economic stabilization and the contradiction that can exist between the respect for fiscal discipline and having a sufficient margin of maneuver to stabilize the economic activity. That is why in order to allow this stabilization, a budgetary position "close to balance or in surplus" in normal times is necessary in order to allow a contracyclical budgetary policy and to increase the budgetary deficit in case of economic downturn. The respect for fiscal rules and fiscal targets would then be a precondition for the possibility of an efficient stabilization of economic shocks in a monetary union. Furthermore, according to Villieu [8], in a monetary union, the optimal contract is to introduce tight public spending targets and loose inflation targets supported by the appropriate penalties. Budgetary policies must be all the more restrictive as asymmetries are large in the monetary union in order to reduce the bias of public spending due to an enlarged and heterogeneous monetary union regarding the monetary policy transmission parameters. Restrictive budgetary policies would thus be beneficial in a monetary union but should go with a less contractionary and a more accommodative monetary policy.

However, can a uniform and same fiscal rule be efficient for all member countries of a heterogeneous monetary union? As mentioned by Buti et al. [9], the appropriate targeted budgetary deficit in normal times for a given country depends on the structural sensitivity of its budgetary deficit to the economic cycle (which is high in particular for the Nordic countries in Europe). Countries with strong automatic stabilizers must secure a higher budgetary surplus in periods of economic growth in order to be allowed to have a higher budgetary deficit in periods of economic recession. In this framework, what is the relative advantage of a rule based on the structural budgetary deficit (as mentioned in the fiscal compact) and not on the global budgetary deficit? Bilbiie and Stasavage [10] show that a rule relying on the structural budgetary deficit implies a complete contract. On the contrary, a rule relying on the current budgetary deficit implies an incomplete contract if the structural budgetary deficit is unobservable. Such a rule implies a procyclical bias which hinders the working of automatic stabilizers. According to the authors, a rule relying on the structural budgetary deficit is thus preferable, provided that estimates of the output gap and of automatic stabilizers are verifiable. Besides, too high and disproportionate penalties could not be enforceable, as they would not be credible, especially if the principal lacks a sufficient reputation for enforcement. Larger announced penalties may lead to diminished beliefs that penalties would be applied.

Regarding monetary policy, Jensen [11] shows that in a stochastic, interdependent world, governments can achieve optimal, cooperative monetary policies by delegating policy conduct to independent central banks. Then, even a stateindependent but quadratic contract with targets can secure that the central bank conducts the optimal cooperative policy for any realization of shocks. However, regarding budgetary policies, the results seem less obvious. Indeed, Manasse [12] shows that deficit-output limits typically induce procyclical policies in intermediate states, and countercyclical policies in very "good" and "bad" states. Indeed, limits are optimally violated in recessions, even if they exert a moderate discipline on deficit spending. Below a given threshold, the government does not want to abide to the excessive deficit limit, since the cost of forgoing stabilization (plus the electoral benefits of the deficits) exceeds the expected penalty. Besides, in intermediate states, budgetary deficits are kept to the threshold to avoid sanctions, which constrains the stabilization policy of the government. However, deficit limits are then found to exert discipline only provided the limit is tight and the expected sanction large, albeit at a relatively large welfare cost.

Besides, long-term considerations, like the level of the public debt and the risks of population ageing, must also be taken into account. That is why Hughes Hallett [13], for example, is in favour of governments focusing on long-term objectives (social security, research, education, infrastructure, and public services), whereas monetary policy would provide short term stabilization. In this framework, according to the author, governments should mainly be concentrated on a flexible goal in terms of public debt, with a "fiscal space" (a target and an upper boundary), a stable region where debt targeting should operate. Soft debt targets are optimal, as they provide enough flexibility in the short run, while focusing on what is the most important and the most credible precommitment: sustainability of public finances in the long 
term. In this context, our model will also study fiscal rules and penalties which could be associated with the deviation not of the structural budgetary deficit but of the public debt level in comparison with a targeted indebtedness level.

Then, what should be the characteristics of the "best" and most appropriate fiscal rules, in the framework of a monetary union? Theoretically, complex and state-contingent rules would be the most optimal. Indeed, Beetsma and Jensen [14] mention that punishing excessive global budgetary deficits may lead to a further deterioration of the budgetary position of a government which has already been hit by a relatively bad shock. An optimal pact should thus make sanctions proportional to the negative shock hitting a country in order to reduce this counterproductive effect; the pact would then provide an automatic insurance against idiosyncratic shocks. However, moral hazard reduces the scope for the contingency of sanctions. In the same way, Villieu [15] shows that delegating monetary policy to an independent central bank with a price stability goal does not allow reaching the best equilibrium. It is necessary to specify a full set of monetary and budgetary contracts. Indeed, a Walsh contract reducing the inflationary bias of monetary policy risks increasing the expansionary bias of the national budgetary policies if the latter cannot commit. The optimal contract for the budgetary authorities is then complex: it is either state-contingent (dependent on symmetric supply or asymmetric shocks) or at least linear-quadratic. However, Villieu [15] underlines the lack of practical usefulness of such contingent contracts. They must specify ex ante a full set of penalties related to the precise nature and width of the shocks, and they are much harder to enforce. That is why the European authorities have chosen contracts which are second best solutions but much easier to implement.

Indeed, Schuknecht [16] stresses the importance of appropriate incentives for rule compliance in an environment where national fiscal sovereignty precludes the option of centralized enforcement. From this viewpoint, European fiscal rules could easily be justified. They are only "soft laws;" but they reduce political transaction costs by improving transparency and providing a forum for peer pressure, and they can also boost incentives towards making the rules "selfenforcing," Clear and simple rules are the most appropriate, because the public's monitoring costs are too high with complex rules; discretion and complex rules make their enforcement more difficult.

Therefore, in the following section, our model aims at defining clear and simple rules that could be optimal in order to incite the decentralized budgetary policies to be closer to the optimal and cooperative budgetary policies. In our model, the fiscal rule would be quite simple, as the member countries of the monetary union would have to pay a fine proportional to the differential between the squared deviation of the structural budgetary deficit or the public debt from their targeted level. However, the optimal fiscal penalties found by our model remain complex, as they depend on the nature of the shocks (symmetric or asymmetric, demand or supply) hitting the member countries of the monetary union, as these penalties are therefore necessarily state-dependent.

\section{A Simple Macroeconomic Model}

In this section, we consider a dynamic open macroeconomic New-Keynesian model, in order to evaluate the optimal weight that should be given to fiscal goals in terms of structural budgetary deficit or of public debt. To this end, we calculate the excess of average welfare loss without budgetary cooperation in comparison with the situation where the budgetary authorities cooperate, in order to estimate the penalties that should be associated with fiscal rules in order to make the decentralized budgetary equilibrium closer to the cooperative and optimal equilibrium. This section defines these optimal fiscal penalties in order to reach a given budgetary or public debt target, whereas the following sections will study the penalties appropriate to stabilize efficiently symmetric or asymmetric demand or supply shocks in a monetary union. All variables are expressed in deviations from their long run equilibrium values. For simplicity, there are only two countries: $(i)$ and $(j)$ in the monetary union, which is supposed to be closed vis-à-vis the rest of the world. The budgetary policies are decided by the decentralized governments, whereas monetary policy is defined by the common central bank of the monetary union.

3.1. The Supply and Demand Functions. We use a stylized dynamic New-Keynesian model, which is broadly consistent with this literature, even if we do not detail here its underlying microeconomic structure (see e.g., Lieb [17] or Galí and Monacelli [18] for the microfoundations of the model). The linearized demand equation for the country $(i)$ in period $(t)$ is

$$
\begin{aligned}
y_{i, t}^{d}= & y_{i, t+1}^{e}-\sigma\left[i_{t}-\pi_{i, t+1}^{e}-r_{i, t}^{*}\right]+\eta\left(\pi_{j, t}-\pi_{i, t}\right) \\
& -(1-\sigma)\left(g_{i, t+1}^{e}-g_{i, t}\right)+\varepsilon_{i, t}^{d} .
\end{aligned}
$$

$0<\sigma<1$ : share of private consumption in GDP, in the efficient steady-state, in comparison with the share of public consumption: $(1-\sigma)$.

$0<\eta<1$ : openness to trade of the member countries of the monetary union.

With, in period $(t)$ in the country $(i)$ : $\left(y_{i, t}\right)$ : output; $\left(g_{i, t}\right)$ : public expenditure; $\left(\pi_{i, t}\right)$ : inflation rate; $\left(r_{i, t}^{*}\right)$ : natural or equilibrium real interest rate; $\left(\varepsilon_{i, t}^{d}\right)$ : demand shock; $\left(\operatorname{def}_{i, t}\right)$ : primary budgetary deficit; and in the monetary union: $\left(i_{t}\right)$ : nominal interest rate; $\left({ }^{e}\right)$ denotes the operator of anticipation, whereas $\left({ }^{*}\right)$ denotes a potential level when economic variables are at their equilibrium value.

Traditionally, in New-Keynesian models, aggregate demand is driven by the optimizing behavior of households, which maximizes an intertemporal utility function. Thus, output depends on expected future output, because rational agents can smooth their consumption intertemporally. Variation in demand is also an increasing function of the variation in public expenditure in a given country in comparison with what is expected for the following period $\left(g_{i, t}-g_{i, t+1}^{e}\right)$. It is a decreasing function of the excess 
of the anticipated real interest rate in the country $(i)$ in comparison with its equilibrium value. Let us mention that for simplification, in this paper, we suppose that the nominal interest rate is the same in all member countries of the monetary union. Indeed, differentials in interest rates have strongly narrowed in Europe after the creation of the EMU, as it was then much more difficult to distinguish between the solvability of the various European countries. However, after 2008, the financial and sovereign debt crisis has worried the financial markets, and the differentials in the risk premiums on interest rates on the public debts of EMU member countries rose again. Nevertheless, even if these differentials could be related to the indebtedness levels of the member countries (the modeling of the current paper could be improved in this direction), the crisis has shown that the opinion of the financial markets on the credibility and on the intertemporal solvability of the budgetary policy of a given country is mainly a question of contagion and of subjective confidence. Therefore, in the current paper, we have considered a uniform nominal interest rate in conformity with the "normal" situation of absence of economic crisis and in order to simplify the formal modeling. Net exports of the country (i) are also an increasing function of its price competitiveness. Finally, variation in demand is an increasing function of a national positive demand shock, which is a white noise: $E_{t}\left(\varepsilon_{i, t}^{d}\right)=0$.

The primary budgetary deficit in the country $(i)$ is the differential between its public expenditures and resources:

$$
\operatorname{def}_{i, t}=g_{i, t}-\tau_{t} y_{i, t}
$$

with $\left(\tau_{t}\right)$ : taxation rate.

The structural primary budgetary deficit depends on structural public expenditure net of structural tax revenues that are realized when the economy is in equilibrium at potential output:

$$
\operatorname{def}_{s i, t}=g_{i, t}^{*}-\tau_{t}^{*} y_{i, t}^{*} .
$$

So, if we split the primary budgetary expenditures and resources of the country $(i)$ between a structural and a conjunctural part, we obtain

$$
\begin{gathered}
g_{i, t}=g_{i, t}^{*}-k\left(y_{i, t}-y_{i, t}^{*}\right), \\
\tau_{t}^{*} y_{i, t}=\tau_{t}^{*} y_{i, t}^{*}+\tau_{t}^{*}\left(y_{i, t}-y_{i, t}^{*}\right),
\end{gathered}
$$

with $(k)$ : GDP elasticity of the deficit or automatic stabilizers.

Therefore, by combining (3) and (4), we have

$$
g_{i, t}=\operatorname{def}_{s i, t}+\left(\tau_{t}^{*}+k\right) y_{i, t}^{*}-k y_{i, t} .
$$

The linearized supply function for the country (i) in period $(t)$ is represented by a forward looking NewKeynesian Phillips curve:

$$
\pi_{i, t}=b \pi_{i, t+1}^{e}+v\left(y_{i, t}^{s}-y_{i, t}^{*}\right)-\varepsilon_{i, t}^{s},
$$

with, in period $(t)$ in the country $(i):\left(\varepsilon_{i, t}^{s}\right)$ : positive supply or productivity shock or negative cost-push shock, which is a white noise. $0<b<1$ is time discount factor; $0<v<1$.
Indeed, in New-Keynesian models, aggregate supply results from the behavior of firms that set prices for their products so as to maximize profits in a monopolistic competition setting. Inflation then depends on expectations about future prices, because of learning effects. Besides, the output gap expresses the demand-pull factor and tensions on the utilization of productive capacities. In this framework, the parameter $(v)$ represents the degree of price flexibility in the monetary union. It is an increasing function of labor market flexibility, of the sensitivity of prices to marginal costs, or of real wages to the number of workers and to unemployment. Finally, $\left(\varepsilon_{i, t}^{s}\right)$ captures a deflationary shock unrelated to excess demand (mark-up, etc.).

Let us suppose that the goal of the common central bank is to preserve price stability in the whole monetary union $\left(\pi_{t}=0\right)$, according to the status of the European Central Bank. In this context, the monetary authority should fix the common nominal interest rate at the following level (see Appendix A):

$$
i_{t}=\frac{(1-\sigma)}{\sigma} \operatorname{def}_{s, t}+f\left(y_{i, t}^{*}, y_{j, t}^{*}, r_{i, t}^{*}, r_{j, t}^{*}\right) .
$$

Therefore, in the framework of our model, the game between the governments and the common central bank can be summarized by conflicting economic policies in the following way. The higher the average structural budgetary deficit in the monetary union, the higher the common interest rate and the more restrictive the common monetary policy. In the same way, the higher the common interest rate, the more expansionary are the budgetary policies in the member countries of the monetary union. Therefore, the monetary authority fully sterilizes the consequences of anticipated budgetary shocks in order to stabilize prices.

In this context, in the short run, according to (1), (6), (7), and (8), if we note that $\varepsilon_{t}=\left(\varepsilon_{i, t}+\varepsilon_{j, t}\right) / 2$ symmetric and $\overline{\varepsilon_{t}}=$ $\left(\varepsilon_{i, t}-\varepsilon_{j, t}\right) / 2$ asymmetric shocks, demand and supply shocks affect prices and economic activity levels in the following way (see Appendix A for the calculations):

$$
\begin{gathered}
\pi_{i, t}=m_{\pi i, \operatorname{def} s i}\left(\operatorname{def}_{s i, t}-\operatorname{def}_{s j, t}\right)+m_{\pi i, \varepsilon_{t}^{d}} \varepsilon_{t}^{d}+m_{\pi i, \overline{\varepsilon_{t}^{d}}} \overline{\varepsilon_{t}^{d}} \\
+m_{\pi i, \varepsilon_{t}^{s}} \varepsilon_{t}^{s}+m_{\pi i, \overline{\varepsilon_{t}^{s}}} \overline{\varepsilon_{t}^{s}}+f\left(y_{i, t}^{*}, y_{j, t}^{*}, r_{i, t}^{*}, r_{j, t}^{*}\right), \\
m_{\pi i, \operatorname{def} s i}=\frac{v(1-\sigma)}{2(1+k-k \sigma+2 v \eta)}, \\
m_{\pi_{i}, \varepsilon_{t}^{d}}=\frac{v}{(1+k-k \sigma)}, \\
m_{\pi_{i}, \overline{\varepsilon_{t}^{d}}}=\frac{v}{(1+k-k \sigma+2 v \eta)}, \\
m_{\pi_{i}, \overline{\varepsilon_{t}^{s}}}=-\frac{(1+k-k \sigma)}{(1+k-k \sigma+2 v \eta)}, \quad m_{\pi_{i}, \varepsilon_{t}^{s}}=-1,
\end{gathered}
$$




$$
\begin{gathered}
y_{i, t}=m_{y i, \operatorname{def} s i}\left(\operatorname{def}_{s i, t}-\operatorname{def}_{s j, t}\right)+m_{y i, \varepsilon_{t}^{d}} \varepsilon_{t}^{d} \\
+m_{y i, \overline{\varepsilon_{t}^{d}}} \overline{\varepsilon_{t}^{d}}+m_{y i, \overline{\varepsilon_{t}^{s}}} \overline{\varepsilon_{t}^{s}}+f\left(y_{i, t}^{*}, y_{j, t}^{*}, r_{i, t}^{*}, r_{j, t}^{*}\right), \\
m_{y i, \operatorname{def} s i}=\frac{(1-\sigma)}{2(1+k-k \sigma+2 v \eta)}, \\
m_{y i, \varepsilon_{t}^{d}}=\frac{1}{(1+k-k \sigma)}, \\
m_{y i, \overline{\varepsilon_{t}^{d}}}=\frac{1}{(1+k-k \sigma+2 v \eta)}, \\
m_{y i, \overline{\varepsilon_{t}^{s}}}=\frac{2 \eta}{(1+k-k \sigma+2 v \eta)} .
\end{gathered}
$$

Therefore, in a given country $(i)$, the inflation rate and the economic activity level are an increasing function of symmetric positive demand shocks. An asymmetric demand shock or an increase in the structural budgetary deficit higher than in the partner country increases inflation and economic activity in the positively affected country, whereas they imply a recession in the negatively affected country. So, it is only a budgetary policy which is differentiated and more expansionary than in the partner country which can stimulate economic growth. There is then an incentive to an excessive budgetary activism in order to influence economic activity and prices according to (9) and (10) and to obtain a competitive advantage in comparison with the foreign country. However, these competitive budgetary policies are useless if they are conducted in parallel in all member countries of the monetary union and, thus, there is a bias of public expenditure.

Besides, symmetric positive supply shocks decrease prices in the whole monetary union without affecting economic activity levels. On the contrary, an asymmetric supply shock implies expansionary and deflationary (recessionary and inflationary) tensions in the country of the monetary union positively (negatively) affected by the shock.

3.2. Determination of Optimal Budgetary Policies. Quadratic contracts prescribe transfer payments that are constantly related to squared deviations of target variables from respective constant target values. So, we suppose that budgetary policies are endogenous and are the result of the minimization of the following quadratic loss function for each government $(i)$ :

$$
\begin{aligned}
L_{i, t}=\frac{1}{2}[ & \alpha_{\pi} \pi_{i, t}^{2}+\alpha_{y}\left(y_{i, t}-y_{i, t}^{*}\right)^{2} \\
& \left.\quad+\alpha_{g, s}\left(\operatorname{def}_{s i, t}-\operatorname{def}_{s}^{T}\right)^{2}+\alpha_{g, d}\left(d_{i, t}-d^{T}\right)^{2}\right]
\end{aligned}
$$

where the parameters $\left(\alpha_{\pi}\right),\left(\alpha_{y}\right)$, and $\left(\alpha_{g}\right)$ express the respective weights of inflation, economic activity, and variation in the budgetary instrument for the government $(i)$, where $(T)$ denotes a targeted value for each fiscal variable. The targeted variation in inflation is zero, in conformity with the goal of price stability, whereas the economic activity target is its potential level. Besides, this loss of function allows studying the consequences of the two budgetary goals pursued by the governments in the framework of the fiscal compact: in terms of structural budgetary deficit $\left(\operatorname{def}_{s}\right)$ with a weight $\left(\alpha_{g, s}\right)$ inclusive of interest payments on the former public debt level or in terms of public debt $(d)$ with a weight $\left(\alpha_{g, d}\right)$ (a goal in terms of structural budgetary deficit $\left(\operatorname{def}_{s i, t}\right)$ inclusive of interest rate payments on the former public debt level $\left(+i_{t} d_{i, t-1}\right)$, as mentioned in the fiscal compact, gives exactly the same results. Indeed, the interest rate on the public debt $\left(i_{t}\right)$ depends on potential economic activity and real interest rate, and on the structural budgetary deficit, which is already a potential variable). These weights are not necessarily equal; they depend on the political costs of potential sanctions that can be associated with the deviation of one budgetary instrument from its targeted value.

If we suppose that the public debt increases with the primary budgetary deficit and with the interest rate charges on this public debt $\left[d_{i, t}=\left(1+i_{t}\right) d_{i, t-1}+\operatorname{def}_{i, t}\right]$, using (2), (6), $(8)$, and (10), the public debt of the country $(i)$ in period $(t)$ in percentage of GDP $\left(d_{i, t}\right)$ is

$$
\begin{aligned}
& d_{i, t}=m_{d i, \text { def } s i} \operatorname{def}_{s i, t}+m_{d i, \text { def } s j} \operatorname{def}_{s j, t} \\
& +m_{d i, \varepsilon_{t}^{d}} \varepsilon_{t}^{d}+m_{d_{i}, \bar{\varepsilon}_{t}^{d}} \overline{\varepsilon_{t}^{d}}+m_{d_{i}, \bar{\varepsilon}_{t}^{s}} \overline{\varepsilon_{t}^{s}}+d_{i, t-1} \\
& +f\left(y_{i, t}^{*}, y_{j, t}^{*}, r_{i, t}^{*}, r_{j, t}^{*}\right) \text {, } \\
& m_{d i, \operatorname{def} s i} \\
& =\left[2 \sigma(1+2 v \eta)+\left(k-\tau_{t}\right) \sigma(1-\sigma)\right. \\
& \left.+(1+k-k \sigma+2 v \eta)(1-\sigma) d_{i, t-1}\right] \\
& \times(2 \sigma(1+k-k \sigma+2 v \eta))^{-1}, \\
& m_{d i, \text { def } s j} \\
& =\frac{\left[(1+k-k \sigma+2 v \eta) d_{i, t-1}+\sigma\left(\tau_{t}+k\right)\right](1-\sigma)}{2 \sigma(1+k-k \sigma+2 v \eta)}, \\
& m_{d i, \varepsilon_{t}^{d}}=\frac{-\left(\tau_{t}+k\right)}{(1+k-k \sigma)}, \\
& m_{d_{i}, \overline{\varepsilon_{t}^{d}}}=-\frac{\left(\tau_{t}+k\right)}{(1+k-k \sigma+2 v \eta)} \\
& m_{d_{i}, \overline{\varepsilon_{t}^{s}}}=-\frac{2 \eta\left(\tau_{t}+k\right)}{(1+k-k \sigma+2 v \eta)} .
\end{aligned}
$$

We suppose that the instrument of the government (i) (variable under control) is its structural primary budgetary deficit $\left(\operatorname{def}_{s i, t}\right)$, as the global budgetary deficit also depends on the economic conjuncture and is thus less easily controllable, whereas the public debt is a variable largely inherited from the past. Using (9), (10), and (12), we calculate the optimal structural primary budgetary deficit of the country $(i)$, which minimizes (11). However, we compare the decentralized and discretionary noncooperative budgetary policies with the optimal and first-best policies that should be conducted in a cooperative framework between the budgetary authorities. 
More precisely, we try to find the optimal fiscal contract and fiscal penalties imposed on the deviation of the structural budgetary deficit or the public debt from their equilibrium values, which could lead the budgetary authorities to conduct the optimal and cooperative budgetary policies, even with decentralized, discretionary, and noncooperative fiscal policies. Therefore, the aim of our model is to find the optimal fiscal penalties $\left(\alpha_{g, s}\right)$ and $\left(\alpha_{g, d}\right)$ in (11), which can implement the cooperative equilibrium (with a superscript "coop") in the noncooperative game (with a superscript "nc"). Our goal is to find the credible (dynamically consistent) delegation parameters of the model; with such a contract, no government would have interest in deviating ex-post from the optimal budgetary policies.

\section{Reaching a Structural Budgetary Deficit or a Public Debt Target}

Let us suppose that the governments have a fiscal rule only in terms of structural budgetary deficit $\left(\alpha_{g, d}=0\right.$ and $\left.\alpha_{g, s}>0\right)$. Then, according to Appendix B, in "normal times" and without supply or demand shocks, the noncooperative and cooperative budgetary policies are exactly identical. The structural budgetary deficit increases in proportion to the structural budgetary deficit target. Indeed, we obtain

$$
\begin{gathered}
\left(\operatorname{def}_{s i, t}+\operatorname{def}_{s j, t}\right)^{\text {coop }}=2 \operatorname{def}_{s}^{T}, \\
\left(\operatorname{def}_{s i, t}+\operatorname{def}_{s j, t}\right)^{\mathrm{nc}}=m_{\operatorname{def} s, \operatorname{def} s T} \operatorname{def}_{s}^{T}=2 \operatorname{def}_{s}^{T} .
\end{gathered}
$$

So, if the public debt levels have no importance for the governments, whatever positive penalty for the deviation of the structural budgetary deficit in comparison with its targeted level is optimal. On the contrary, conducting the optimal fiscal policy in order to reach a given public debt target is a little bit more complex.

With a goal in terms of public debt $\left(\alpha_{g, d}>0\right.$ and $\left.\alpha_{g, s}=0\right)$ if the budgetary authorities cooperate, the optimal budgetary policies should be contractionary if the previous public debt levels were higher than the targeted levels. According to Appendix B, we have

$$
\left(\operatorname{def}_{s i, t}+\operatorname{def}_{s j, t}\right)^{\text {coop }}=-\frac{2 \sigma\left(d_{i, t-1}+d_{j, t-1}-2 d^{T}\right)}{\left[2 \sigma+(1-\sigma)\left(d_{i, t-1}+d_{j, t-1}\right)\right]} .
$$

Indeed, a smaller structural budgetary deficit is necessary in order to decrease the common interest rate on previous public debt levels and to decrease the indebtedness levels of the member countries of the monetary union. Without budgetary cooperation, the budgetary policy is also contractionary in a given country if its indebtedness level was formerly higher than the targeted level. Indeed, according to the values mentioned in Appendix B, we have

$$
\begin{aligned}
\left(\operatorname{def}_{s i, t}+\operatorname{def}_{s j, t}\right)^{\mathrm{nc}}= & m_{\operatorname{def} s, d i T}\left(d_{i, t-1}-d^{T}\right) \\
& +m_{\operatorname{def} s, d j T}\left(d_{j, t-1}-d^{T}\right),
\end{aligned}
$$

with $m_{\text {def } s, d i T}<0, m_{\text {def } s, d j T}<0$.
However, the budgetary policies can then be insufficiently contractionary. Indeed, each budgetary authority is not active enough in reducing its structural budgetary deficit, as it does not take into account the beneficial effect of the reduction in the common interest rate also on the indebtedness level of the foreign country.

So, what are then the optimal penalties on public debt levels in order to lead the governments to conduct the optimal budgetary policies and to imply automatically without cooperation the appropriate reduction in the structural budgetary deficits? According to the differential in welfare loss functions given in Appendix B

$$
\begin{gathered}
\frac{\partial\left[\partial\left(L_{t}^{\mathrm{nc}}-L_{t}^{\text {coop }}\right) / \partial\left(d_{i, t-1}-d^{T}\right)^{2}\right]}{\partial \alpha_{g, d}}=0 \text { implies: } \\
\left\{2 \sigma+m_{\operatorname{def} s, d i T}\left[2 \sigma+(1-\sigma)\left(d_{i, t-1}+d_{j, t-1}\right)\right]\right\} \\
\times\left\{2 \sigma+\left[m_{\operatorname{def} s, d i T}+2 \alpha_{g, d} \frac{\partial m_{\text {def } s, d i T}}{\partial \alpha_{g, d}}\right]\right. \\
\left.\times\left[2 \sigma+(1-\sigma)\left(d_{i, t-1}+d_{j, t-1}\right)\right]\right\}=0 .
\end{gathered}
$$

Therefore, with the expression of $\left(\operatorname{def}_{s}\right)$ mentioned in Appendix B, this implies:

$$
\begin{aligned}
& -\left[\sigma+(1-\sigma) d_{j, t-1}\right]^{2} \frac{(1-\sigma)^{8}\left(\alpha_{\pi} v^{2}+\alpha_{y}\right)^{3}}{32 \sigma^{2}(1+k-k \sigma+2 v \eta)^{6} \Delta_{\text {def } s}^{3}} \\
& \times\left(d_{i, t-1}-d_{j, t-1}\right)^{2} \\
& \times\left\{2 \alpha_{g, d} m_{d i, \operatorname{def} s i} m_{d j, \operatorname{def} s j}\right. \\
& \quad \times \frac{\left(1-\tau_{t}+\sigma \tau_{t}+2 v \eta\right)(1+k-k \sigma+2 v \eta)}{(1-\sigma)^{2}\left(\alpha_{\pi} v^{2}+\alpha_{y}\right)} \\
& \quad \times\left[2 \sigma+(1-\sigma)\left(d_{i, t-1}+d_{j, t-1}\right)\right] \\
& -m_{d j, \operatorname{def} s j}\left[d_{j, t-1}(1-\sigma)+\sigma\right] \\
& \left.-m_{d i, \operatorname{def} s i}\left[d_{i, t-1}(1-\sigma)+\sigma\right]\right\}=0 .
\end{aligned}
$$

So, whatever sanction related to the indebtedness level is optimal provided the public debt levels are the same in the member countries of the monetary union $\left(d_{i, t-1}=d_{j, t-1}\right)$. It is then only the speed of convergence towards the targeted debt level which can vary according to the height of the penalty related to the fiscal goal. Otherwise, if the public debt levels are distinct between the member countries of the monetary union, according to the value of $\left(m_{d i \text {,def } s i}\right)$ in (12), a positive 
penalty on the excessive debt levels is necessary, which is as follows:

$$
\begin{aligned}
\alpha_{g, d}= & \sigma(1-\sigma)^{2}\left(\alpha_{\pi} v^{2}+\alpha_{y}\right) \\
\times & \left(\left(1-\tau_{t}+\sigma \tau_{t}+2 v \eta\right)\right. \\
& \left.\times\left[2 \sigma+(1-\sigma)\left(d_{i, t-1}+d_{j, t-1}\right)\right]\right)^{-1} \\
\times & \left\{\left(\left[d_{j, t-1}(1-\sigma)+\sigma\right]\right.\right. \\
& \times\left(\left[2 \sigma(1+2 v \eta)+\left(k-\tau_{t}\right) \sigma(1-\sigma)\right.\right. \\
& \left.\left.\left.+(1+k-k \sigma+2 v \eta)(1-\sigma) d_{i, t-1}\right]\right)^{-1}\right) \\
+ & \left(\left[d_{i, t-1}(1-\sigma)+\sigma\right]\right. \\
& \times\left(\left[2 \sigma(1+2 v \eta)+\left(k-\tau_{t}\right) \sigma(1-\sigma)\right.\right. \\
& \left.\left.\left.\left.+(1+k-k \sigma+2 v \eta)(1-\sigma) d_{j, t-1}\right]\right)^{-1}\right)\right\} .
\end{aligned}
$$

Therefore, the optimal penalty on the excessive public debt level $\left(\alpha_{g, d}\right)$ should be quite small; it should be around (0.02) with the basic calibration of our parameters and much smaller than the weight given to the price stability goal or to the stabilization of economic activity levels. Besides, according to the previous equation (18), this optimal penalty decreases with the parameters $(\sigma),(\eta),(k)$, and $(v)$. Indeed, according to (8), a higher share of private consumption in GDP $(\sigma)$ reduces the monetary reaction to higher structural budgetary deficits in the monetary union, as the increase in the common interest rate is then more efficient. In these conditions, it is thus less necessary to encourage the governments to conduct active and contractionary budgetary policies intended to limit interest rate charges and to reduce excessive public debt levels, and the fiscal goal can have a smaller weight. In the same way, a higher openness to trade $(\eta)$, a higher price flexibility $(v)$, and stronger automatic stabilizers $(k)$ reduce the budgetary activism: the height of the fiscal penalty can then be reduced.

On the contrary, higher taxation rates $(\tau)$ increase the tendency to conduct active budgetary policies, as they are then more efficient; the weight of the fiscal goal must then be higher. Finally, the optimal penalty on the deviation of the public debt with its targeted level must also slightly increase with the differential indebtedness levels between the member countries of the monetary union. Indeed, if the public debt levels are very different between the member countries of the monetary union, the common interest rate is too high for the country with the smallest structural budgetary deficit but too small for the country with the highest structural budgetary deficit. Therefore, the speed of convergence towards the targeted public debt levels must be accentuated in order to allow a more efficient common monetary policy.

Finally, the simple modeling of the current paper only considers the interaction between two member countries of a monetary union. However, we can mention that if the number of countries increases in the monetary union, each country has a weaker influence on the average structural budgetary deficit and on the common interest rate in (8). Therefore, optimal fiscal penalties in order to limit the budgetary activism, interest rate charges on the public debts, and to reduce public indebtedness levels could be weaker and would probably decrease with the width and the number of countries in the monetary union.

\section{Stabilization of Asymmetric Shocks}

5.1. Asymmetric Supply Shocks. An asymmetric supply shock implies deflationary and expansionary (inflationary and recessionary) tensions in the country positively (negatively) affected by the shock. So, the budgetary policy can only be moderately contractionary (expansionary) in the positively (negatively) affected country in order to stabilize economic activity levels without excessively destabilizing prices and public expenditures. Anyway, if the member countries of the monetary union have a goal in terms of structural budgetary deficit $\left(\alpha_{g, s}>0\right.$ and $\left.\alpha_{g, d}=0\right)$, their budgetary policies are exactly opposite in case of asymmetric supply shocks, whether their policies are coordinated or not. Indeed, according to the values in Appendix B, we obtain

$$
\left(\operatorname{def}_{s i, t}+\operatorname{def}_{s j, t}\right)^{\mathrm{nc}}=\left(\operatorname{def}_{s i, t}+\operatorname{def}_{s j, t}\right)^{\text {coop }}=0 \overline{\varepsilon_{t}^{s}} .
$$

In the country positively affected by the supply shock, reducing the public expenditure would worsen the deflationary tensions, whereas the reduction in the expansionary tensions would be mitigated by the increase in pricecompetitiveness and in national exports. To the contrary, in the country negatively affected by the shock, increasing the public expenditure would worsen the inflationary tensions, whereas the reduction in the recessionary tensions would be mitigated by the decrease in national exports. Thus, optimal budgetary policies remain only moderately active with or without budgetary cooperation. In this framework, a penalty on the excessive structural budgetary deficit is useless in case of asymmetric supply shocks.

The situation is a little bit more complex if the budgetary authorities have a goal in terms of public debt $\left(\alpha_{g, d}>\right.$ 0 and $\left.\alpha_{g, s}=0\right)$. Indeed, we have seen that budgetary activism in order to stabilize asymmetric supply shocks should remain quite limited. Besides, the average structural budgetary balance should be zero in the monetary union if the budgetary authorities coordinate their economic policies. However, decentralized budgetary policies have a tendency to be too active as soon as public indebtedness levels are distinct between the member countries of the monetary union. 
Indeed, according to the values obtained in Appendix B, we have

$$
\begin{aligned}
& \left(\operatorname{def}_{s i, t}+\operatorname{def}_{s j, t}\right)^{\mathrm{nc}}=m_{\operatorname{def} s, \bar{\varepsilon}_{t}} \overline{\varepsilon_{t}^{s}}, \\
m_{\text {def } s, \overline{\varepsilon_{t}^{s}}}= & \frac{\alpha_{g, d}(1-\sigma)\left(d_{i, t-1}-d_{j, t-1}\right)}{\sigma(1+k-k \sigma+2 v \eta) \Delta_{\text {def } s}} \\
\times & \left\{\eta\left(\tau_{t}+k\right) \alpha_{g, d}\right. \\
& \times\left(m_{d j, \text { def } s j} m_{d j, \operatorname{def} s i}+m_{d i, \operatorname{def} s i} m_{d i, \text { def } s j}\right) \\
& +\frac{\left(1-\tau_{t}+\sigma \tau_{t}+2 v \eta\right)(1-\sigma)}{4(1+k-k \sigma+2 v \eta)^{2}} \\
& \left.\times\left[2 \eta \alpha_{y}-\alpha_{\pi} v(1+k-k \sigma)\right]\right\} .
\end{aligned}
$$

Therefore, noncooperative budgetary policies tend to be expansionary on average if the country (i) positively affected by the asymmetric supply shock is the one with the highest public debt level. Indeed, in order to reduce the differential in public indebtedness levels between the member countries of the monetary union and to make them converge towards a targeted level, the structural budgetary deficit must be smaller in the most indebted country (i). Then, the higher relative structural budgetary deficit which is allowed in the country ( $j$ ) increases its economic activity and prices. Besides, if this country is negatively affected by an asymmetric supply shock, this deficit can be encouraged as it reduces the recessionary tensions in this country. On the contrary, noncooperative budgetary policies have a tendency to be too contractionary on average if the country (i) positively affected by the shock is the one with the smallest public debt level.

In this framework, as the average structural budgetary deficit should be zero in case of asymmetric supply shocks in a cooperative framework, in order to avoid an inefficient budgetary activism, what is the optimal fiscal penalty to impose on excessive public debt levels? According to the values in Appendix B:

$$
\frac{\partial\left[\partial\left(L_{t}^{\mathrm{nc}}-L_{t}^{\mathrm{coop}}\right) / \partial \overline{\varepsilon_{t}^{s 2}}\right]}{\partial \alpha_{g, d}}=0
$$

implies: $m_{\operatorname{def} s, \overline{\varepsilon_{t}^{s}}}\left[m_{\operatorname{def} s, \overline{\varepsilon_{t}^{s}}}+2 \alpha_{g, d} \frac{\partial m_{\mathrm{def} s, \overline{\varepsilon_{t}^{s}}}}{\partial \alpha_{g, d}}\right]=0$.

With the expression of the parameters mentioned in Appendix B, we obtain

$$
\begin{aligned}
(1 & -\sigma)\left(d_{i, t-1}-d_{j, t-1}\right) m_{\text {def } s, \bar{s}_{t}^{s}} \\
& \times\left(8 \sigma^{2} \Delta_{\text {def } s}^{2} \alpha_{g, d}(1+k-k \sigma+2 v \eta)^{2} m_{d i, \text { def } s i} m_{d j, \operatorname{def} s j}\right)^{-1} \\
& \times\left\{\frac{(1-\sigma)^{2}}{(1+k-k \sigma+2 v \eta)}\left(\alpha_{\pi} v^{2}+\alpha_{y}\right)\right.
\end{aligned}
$$

$$
\begin{aligned}
& \times\left[\left(2 \alpha_{y} \eta-\alpha_{\pi} v(1+k-k \sigma)\right)\right. \\
& \times \frac{(1-\sigma)\left(1-\tau_{t}+\sigma \tau_{t}+2 v \eta\right)}{2(1+k-k \sigma+2 v \eta)^{2}} \\
& +6 \alpha_{g, d} \eta\left(\tau_{t}+k\right) \\
& \left.\times\left(m_{d i, \operatorname{def} s i} m_{d i, \operatorname{def} s j}+m_{d j, \operatorname{def} s j} m_{d j, \text { def } s i}\right)\right] \\
& \times\left[\frac{d_{j, t-1}(1-\sigma)}{m_{d i, \text { def } s i}}+\frac{\sigma}{m_{d i \text { def } s i}}\right. \\
& \left.+\frac{d_{i, t-1}(1-\sigma)}{m_{d j, \text { def } s j}}+\frac{\sigma}{m_{d j, \text { def } s j}}\right] \\
& +\alpha_{g, d}\left[2 \sigma+(1-\sigma)\left(d_{i, t-1}+d_{j, t-1}\right)\right] \\
& \times\left(1-\tau_{t}+\sigma \tau_{t}+2 v \eta\right) \\
& \times\left[4 \eta\left(\tau_{t}+k\right) \alpha_{g, d}\right. \\
& \times\left(m_{d i, \text { def } s i} m_{d i, \text { def } s j}+m_{d j, \text { def } s j} m_{d j \text {,def } s i}\right) \\
& -(1-\sigma)\left(2 \alpha_{y} \eta-\alpha_{\pi} v(1+k-k \sigma)\right) \\
& \left.\left.\times \frac{\left(1-\tau_{t}+\sigma \tau_{t}+2 v \eta\right)}{(1+k-k \sigma+2 v \eta)^{2}}\right]\right\}=0 .
\end{aligned}
$$

So, as the economic activity target has usually the highest weight for the governments $\left(\alpha_{y}>\alpha_{\pi}\right)$, either public debt levels are identical in the member countries of the monetary union $\left(d_{i, t-1}=d_{j, t-1}\right)$ or the expression in parentheses equals zero in (22). This second degree equation has then two roots, which are quite small, for the optimal penalties on the excessive public debt levels $\left(\alpha_{g, d}\right)$. However, (22) shows that the cooperative equilibrium can be reached thanks to a moderate penalty on the excessive public debt level only if the share of the private sector in GDP $(\sigma)$, openness to trade $(\eta)$, and price flexibility $(v)$ are sufficiently high, whereas on the contrary automatic stabilizers $(k)$, taxation rates $\left(\tau_{t}\right)$, and public indebtedness levels $\left(d_{t-1}\right)$ are sufficiently small in the member countries of the monetary union.

Furthermore, our results are ambiguous regarding the consequences of a variation in these parameters. Indeed, the optimal penalty on the public debt level is not the same for both member countries of the monetary union. Therefore, the first and smallest root of (22) is a decreasing function of the share of private consumption in GDP $(\sigma)$, of the openness to trade $(\eta)$, and of price flexibility $(v)$ in the monetary union, and an increasing function of automatic stabilizers $(k)$, of taxation rates $\left(\tau_{t}\right)$, of the public indebtedness levels $\left(d_{t-1}\right)$, and of the differential in these indebtedness levels between the member countries of the monetary union. But the results 
are exactly the opposite for the second and highest root of (22), which is an increasing function of $(\sigma),(\eta)$, and $(v)$ but a decreasing function of $(k),\left(\tau_{t}\right)$, and $\left(d_{t-1}\right)$.

5.2. Asymmetric Demand Shocks. An asymmetric demand shock implies inflationary and expansionary (deflationary and recessionary) tensions in the country positively (negatively) affected by the shock. Therefore, the country positively affected by the shock must conduct a more contractionary budgetary policy, whereas the country negatively affected by the shock must conduct a more expansionary budgetary policy. If the member countries of the monetary union have a goal in terms of structural budgetary deficit $\left(\alpha_{g, s}>0\right.$ and $\alpha_{g, d}=0$ ), the average budgetary policy is then unchanged in case of an asymmetric demand shock. Indeed, the higher structural budgetary deficit in the country negatively affected by the shock is exactly compensated by the higher structural budgetary surplus in the country positively affected by the shock, whether their policies are coordinated or not. Indeed, according to the values in Appendix B, we obtain

$$
\left(\operatorname{def}_{s i, t}+\operatorname{def}_{s j, t}\right)^{\mathrm{nc}}=\left(\operatorname{def}_{s i, t}+\operatorname{def}_{s j, t}\right)^{\text {coop }}=0 \overline{\varepsilon_{t}^{d}} .
$$

In the country positively affected by the asymmetric demand shock, decreasing the public expenditure reduces the expansionary tensions due to the shock. On the contrary, in the country negatively affected by the shock, increasing the public expenditure reduces the recessionary tensions due to the shock. However, the average structural budgetary deficit is unchanged, with or without budgetary cooperation. In this framework, a penalty on the excessive structural budgetary deficit is useless and would even be harmful in case of asymmetric demand shocks.

The situation is a little bit more complex if the budgetary authorities have a goal in terms of public debt $\left(\alpha_{g, d}>0\right.$ and $\alpha_{g, s}=0$ ). Indeed, the budgetary policy is efficiently more contractionary in the country positively affected and more expansionary in the country negatively affected by the asymmetric demand shock. However, these budgetary policies have a tendency to be excessively active as soon as public indebtedness levels are distinct between the member countries of the monetary union. Indeed, according to the values obtained in Appendix B, we have

$$
\begin{gathered}
\left(\operatorname{def}_{s i, t}+\operatorname{def}_{s j, t}\right)^{\mathrm{nc}}=m_{\text {def } s, \varepsilon_{t}^{d}} \overline{\varepsilon_{t}^{d}}, \\
m_{\text {def } s, \overline{\varepsilon_{t}^{d}}}=\frac{\alpha_{g, d}(1-\sigma)\left(d_{i, t-1}-d_{j, t-1}\right)}{2 \sigma(1+k-k \sigma+2 v \eta) \Delta_{\text {def } s}} \\
\times\left[\alpha_{g, d}\left(\tau_{t}+k\right)\right. \\
\times\left(m_{d i, \operatorname{def} s i} m_{d i, \operatorname{def} s j}+m_{d j, \operatorname{def} s j} m_{d j, \operatorname{def} s i}\right)
\end{gathered}
$$

$$
\begin{aligned}
& +\frac{(1-\sigma)\left(1-\tau_{t}+\sigma \tau_{t}+2 v \eta\right)}{2(1+k-k \sigma+2 v \eta)^{2}} \\
& \left.\times\left(\alpha_{\pi} v^{2}+\alpha_{y}\right)\right] .
\end{aligned}
$$

Therefore, noncooperative budgetary policies tend to be expansionary on average if the country (i) positively affected by the asymmetric demand shock is the one with the highest public debt level. Indeed, in order to reduce the differential in public indebtedness levels between the member countries of the monetary union and to make them converge towards a targeted level, the structural budgetary surplus should still be higher in the most indebted country $(i)$ positively affected by the shock. Nevertheless, even if the smaller public debt level in the country $(j)$ reduces the structural budgetary deficit necessary in this country, the latter remains nonnegligible in order to compensate for the recessionary consequences of the asymmetric negative demand shock. On the contrary, noncooperative budgetary policies have a tendency to be contractionary on average if the country $(i)$ positively affected by the demand shock is the one with the smallest public debt level.

In this framework, as the average structural budgetary balance should be zero in case of asymmetric demand shocks in a cooperative framework, in order to avoid an inefficient budgetary activism, what is the optimal fiscal penalty to impose on the excessive public debt level? According to the values in Appendix B:

$$
\begin{aligned}
& \frac{\partial\left[\partial\left(L_{t}^{\mathrm{nc}}-L_{t}^{\mathrm{coop}}\right) / \partial \overline{\varepsilon_{t}^{d 2}}\right]}{\partial \alpha_{g, d}}=0 \\
& \text { implies: } m_{\operatorname{def} s, \overline{\varepsilon_{t}^{d}}}\left[m_{\operatorname{def} s, \overline{\varepsilon_{t}^{d}}}+2 \alpha_{g, d} \frac{\partial m_{\operatorname{def} s, \overline{\varepsilon_{t}^{d}}}}{\partial \alpha_{g, d}}\right]=0 .
\end{aligned}
$$

With the expression of the parameters mentioned in Appendix B, we obtain

$$
\begin{aligned}
& (1-\sigma)\left(d_{i, t-1}-d_{j, t-1}\right) m_{\mathrm{def} s, \varepsilon_{t}^{\bar{d}}} \\
& \times\left(8 \alpha_{g, d} \sigma^{3}(1+k-k \sigma+2 v \eta)^{2}\right. \\
& \left.\times \Delta_{\text {def } s}^{2} m_{d i, \text { def } s i} m_{d j, \text { def } s j}\right)^{-1} \\
& \times\left\{(1-\sigma)^{2}\left(\alpha_{\pi} v^{2}+\alpha_{y}\right)\right. \\
& \times\left[\left(\alpha_{\pi} v^{2}+\alpha_{y}\right) \frac{(1-\sigma)\left(1-\tau_{t}+\sigma \tau_{t}+2 v \eta\right)}{2(1+k-k \sigma+2 v \eta)^{3}}\right. \\
& +3 \alpha_{g, d} \frac{\left(\tau_{t}+k\right)}{(1+k-k \sigma+2 v \eta)} \\
& \left.\times\left(m_{d i, \text { def } s i} m_{d i, \text { def } s j}+m_{d j, \operatorname{def} s j} m_{d j, \text { def } s i}\right)\right]
\end{aligned}
$$




$$
\begin{aligned}
& \times\left[\frac{d_{j, t-1}(1-\sigma)}{m_{d i, \text { def } s i}}+\frac{\sigma}{m_{d i, \text { def } s i}}\right. \\
& \left.\quad+\frac{d_{i, t-1}(1-\sigma)}{m_{d j, \text { def } s j}}+\frac{\sigma}{m_{d j, \text { def } s j}}\right] \\
& -\alpha_{g, d}\left[2 \sigma+(1-\sigma)\left(d_{i, t-1}+d_{j, t-1}\right)\right] \\
& \times\left[(1-\sigma)\left(\alpha_{\pi} v^{2}+\alpha_{y}\right) \frac{\left(1-\tau_{t}+\sigma \tau_{t}+2 v \eta\right)^{2}}{(1+k-k \sigma+2 v \eta)^{2}}\right. \\
& \quad-2 \alpha_{g, d}\left(\tau_{t}+k\right)\left(1-\tau_{t}+\sigma \tau_{t}+2 v \eta\right) \\
& \left.\left.\times\left(m_{d i, \text { def } s i} m_{d i, \text { def } s j}+m_{d j, \text { def } s j} m_{d j, \text { def } s i}\right)\right]\right\} .
\end{aligned}
$$

So, either the public debt levels are identical in the member countries of the monetary union $\left(d_{i, t-1}=d_{j, t-1}\right)$ or the expression in parentheses equals zero in (26). This second degree equation has then two roots, which are quite small, for the optimal penalties on the excessive public debt levels $\left(\alpha_{g, d}\right)$. However, (26) shows that the cooperative equilibrium can be reached thanks to a moderate penalty on the excessive public debt level only if the share of the private sector in GDP $(\sigma)$, openness to trade $(\eta)$, and price flexibility $(v)$ are sufficiently high, whereas on the contrary automatic stabilizers $(k)$, taxation rates $\left(\tau_{t}\right)$, and public indebtedness levels $\left(d_{t-1}\right)$ are sufficiently small in the member countries of the monetary union.

Furthermore, our results are ambiguous regarding the consequences of a variation in these parameters. Indeed, the optimal penalty on the public debt level is not the same for both member countries of the monetary union. Therefore, the first and smaller root of (26) ( 0.05 with our basic calibration) is a decreasing function of the share of private consumption in $\operatorname{GDP}(\sigma)$, of the openness to trade $(\eta)$, and of price flexibility $(v)$ in the monetary union and an increasing function of automatic stabilizers $(k)$, of taxation rates $\left(\tau_{t}\right)$, of the public indebtedness levels $\left(d_{t-1}\right)$, and of the differential in these indebtedness levels between the member countries of the monetary union. But the results are exactly the opposite for the second and higher root of (26) (0.08 with our basic calibration), which is an increasing function of $(\sigma),(\eta)$, and $(v)$ but a decreasing function of $(k),\left(\tau_{t}\right)$, and $\left(d_{t-1}\right)$.

\section{Stabilization of Symmetric Shocks}

6.1. Symmetric Supply Shocks. Positive symmetric supply shocks decrease prices without affecting economic activity levels in the monetary union, according to (9) and (10). Besides, economic activity levels and prices only depend on the differential between fiscal policies. So, active budgetary policies are useless; indeed, if the other countries conduct the same policies, economic variables are unchanged. Therefore,budgetary authorities should not react and try to stabilize symmetric supply shocks in a cooperative and optimal economic framework (see Appendix B).

However, with a fiscal rule in terms of structural budgetary deficit $\left(\alpha_{g, d}=0\right.$ and $\left.\alpha_{g, s}>0\right)$, budgetary policies are tempted to be expansionary after a positive symmetric supply shock without budgetary cooperation. According to the values mentioned in Appendix B, we have

$$
\begin{aligned}
m_{\mathrm{def} s, \varepsilon_{t}^{s}} & =-\frac{2 \alpha_{\pi} m_{\pi i, \mathrm{def} s i} m_{\pi i, \varepsilon_{t}^{s}}}{\alpha_{g, s}} \\
& =\frac{\alpha_{\pi} v(1-\sigma)}{\alpha_{g, s}(1+k-k \sigma+2 v \eta)}>0
\end{aligned}
$$

Indeed, specific national economic activity levels do not depend on symmetric supply shocks. Nevertheless, the preference for price stability can lead to conduct expansionary budgetary policies in order to limit the national deflationary tensions due to a positive supply shock, hoping that the foreign country will not act the same way. However, this excessive budgetary activism in a noncooperative framework can be reduced thanks to a penalty on the excessive structural budgetary deficit. Indeed, according to the values given in Appendix B:

$$
\begin{aligned}
& \operatorname{Min}\left\{\frac{\partial\left[\partial\left(L_{t}^{\mathrm{nc}}-L_{t}^{\mathrm{coop}}\right) / \partial \varepsilon_{t}^{s 2}\right]}{\partial \alpha_{g, s}}\right\} \\
& =\operatorname{Min}\left\{m_{\mathrm{def} s, \varepsilon_{t}^{s}}\left[m_{\mathrm{def} s, \varepsilon_{t}^{s}}+2 \alpha_{g, s} \frac{\partial m_{\mathrm{def} s, \varepsilon_{t}^{s}}}{\partial \alpha_{g, s}}\right]\right\} \\
& =\operatorname{Min}\left\{\frac{\alpha_{\pi}^{2} v^{2}(1-\sigma)^{2}}{\alpha_{g, s}^{2}(1+k-k \sigma+2 v \eta)^{2}}\right\} .
\end{aligned}
$$

Therefore, the fiscal penalty on the excessive structural budgetary deficit should be as high as possible in order to constrain the excessively expansionary noncooperative budgetary policies and to make them closer to the inactive optimal budgetary policies. Besides, this penalty should increase with the share of public expenditure in GDP ( $\sigma$ is small), with price flexibility ( $v$ is high), and decrease with automatic stabilizers $(k)$ and openness to trade $(\eta)$ in the monetary union. Indeed, these characteristics tend to increase the intensity of budgetary activism.

With a goal in terms of public debt $\left(\alpha_{g, d}>0\right.$ and $\alpha_{g, s}=$ $0)$, budgetary policies are also tempted to be expansionary $\left(m_{\mathrm{def} s, \varepsilon_{t}^{s}}>0\right)$ in order to compensate for the deflationary consequences of the shock, while they should be inactive. 
Besides, according to the values mentioned in Appendix B, we have

$$
\begin{aligned}
& \operatorname{Min}\left\{\frac{\partial\left[\partial\left(L_{t}^{\mathrm{nc}}-L_{t}^{\mathrm{coop}}\right) / \partial \varepsilon_{t}^{s 2}\right]}{\partial \alpha_{g, d}}\right\} \operatorname{Min}\left\{m_{\operatorname{def} s, \varepsilon_{t}^{s}}\left[m_{\mathrm{def} s, \varepsilon_{t}^{s}}+2 \alpha_{g, d} \frac{\partial m_{\mathrm{def} s, \varepsilon_{t}^{s}}}{\partial \alpha_{g, d}}\right]\right\} \\
&=\operatorname{Min}\left\{\alpha_{\pi}^{2} \alpha_{g, d}^{4} P v^{2}(1-\sigma)^{2}\right. \\
& \times\left(8(1+k-k \sigma+2 v \eta)^{5} \sigma^{2} \Delta_{\text {def } s}^{3} m_{d i, \mathrm{def} s i} m_{d j, \mathrm{def} s j}\right)^{-1} \\
& \times\left[\frac{\left(\alpha_{\pi} v^{2}+\alpha_{y}\right)}{\alpha_{g, d}} \frac{(1-\sigma)^{2}}{(1+k-k \sigma+2 v \eta)}\right. \\
&+\left(1-\tau_{t}+\sigma \tau_{t}+2 v \eta\right) \\
&\left.\left.\quad \times\left(m_{d i, \mathrm{def} s i}+m_{d j, \mathrm{def} s j}\right)\right]\right\}
\end{aligned}
$$

As the parameter $P$ is positive with plausible values of the parameters of our model and is a decreasing function of $\left(\alpha_{g, d}\right)$ (the precise value of $P$ is given in Appendix C) and as $\left(\Delta_{\text {def } s}^{3}\right)$ depends on $\left(\alpha_{g, d}^{6}\right)$ we find the same result as for a fiscal rule in terms of structural budgetary deficit. The fiscal penalty on the excessive public debt level should be as high as possible in order to constrain the excessively expansionary noncooperative budgetary policies and to make them closer to the inactive optimal and cooperative budgetary policies.

Nevertheless, in case of symmetric supply shocks, a fiscal penalty on the public debt level $\left(\alpha_{g, d}\right)$ seems more efficient than a penalty on the structural budgetary deficit. Indeed, the expression to minimize in (29) is smaller than the expression in (28), according to the basic calibration of our parameters. As previously mentioned, the fiscal penalty should decrease with the parameters $(\sigma)$ and $(\eta)$ and increase with $(v)$. Furthermore, a fiscal penalty on the public debt level could also decrease with the previous public debt levels $\left(d_{i, t-1}\right.$ and $\left.d_{j, t-1}\right)$, as high indebtedness levels make such a penalty more efficient in order to constrain the budgetary activism. This penalty should also rise with taxation rates $\left(\tau_{t}\right)$, which increase the weight of the public sector and the budgetary activism.

6.2. Symmetric Demand Shocks. According to (9) and (10), fiscal policies have no consequences on prices and economic activity levels if they are similar in the member countries of the monetary union. So, if these countries have a fiscal rule in terms of structural budgetary deficit $\left(\alpha_{g, s}>0\right.$ and $\alpha_{g, d}=0$ ), active budgetary policies are useless; indeed, if the other countries conduct the same policies, economic variables are unchanged. Therefore, budgetary authorities should not react and try to stabilize symmetric demand shocks in a cooperative and optimal economic framework (see Appendix B).

However, symmetric demand shocks imply expansionary and inflationary tensions in the member countries of the monetary union. Therefore, the countries can be tempted to conduct active and contractionary budgetary policies in order to compensate for the consequences of the shock. Indeed, according to the value mentioned in Appendix B, we have

$$
m_{\mathrm{def} s, \varepsilon_{t}^{d}}=-\frac{\left(\alpha_{\pi} v^{2}+\alpha_{y}\right)(1-\sigma)}{\alpha_{g, s}(1+k-k \sigma)(1+k-k \sigma+2 v \eta)}<0 .
$$

However, the excessive budgetary activism in a noncooperative framework can be reduced thanks to a penalty on the excessive structural budgetary deficit. Indeed, according to the values given in Appendix B, we obtain

$$
\begin{aligned}
& \operatorname{Min}\left\{\frac{\partial\left[\partial\left(L_{t}^{\mathrm{nc}}-L_{t}^{\mathrm{coop}}\right) / \partial \varepsilon_{t}^{d 2}\right]}{\partial \alpha_{g, s}}\right\} \\
& =\operatorname{Min}\left\{m_{\mathrm{def} s, \varepsilon_{t}^{d}}\left[m_{\mathrm{def} s, \varepsilon_{t}^{d}}+2 \alpha_{g, s} \frac{\partial m_{\mathrm{def} s, \varepsilon_{t}^{d}}}{\partial \alpha_{g, s}}\right]\right\} \\
& =\operatorname{Min}\left\{\frac{\left(\alpha_{\pi} v^{2}+\alpha_{y}\right)^{2}(1-\sigma)^{2}}{\alpha_{g, s}^{2}(1+k-k \sigma)^{2}(1+k-k \sigma+2 v \eta)^{2}}\right\} .
\end{aligned}
$$

Therefore, the fiscal penalty on the excessive structural budgetary deficit should be as high as possible in order to constrain the excessively contractionary noncooperative budgetary policies and to make them closer to the inactive optimal budgetary policies. Besides, this penalty should increase with the share of public expenditure in GDP ( $\sigma$ is small), and it should decrease with price flexibility $(v)$, automatic stabilizers $(k)$, and openness to trade $(\eta)$ in the monetary union. Indeed, these characteristics tend to increase the intensity of budgetary activism, whereas the latter must be constrained. More precisely, the share of governments in the stabilization of symmetric demand shocks increases with the parameter $(1-\sigma)$, in comparison to the one of the common central bank. Besides, a country can be discouraged from conducting a more contractionary budgetary policy than its partners if the member countries of the monetary union are very open, as a relatively weaker economic growth would improve its price-competitiveness, would increase its exports, and would make more difficult the fight against expansionary tensions. On the contrary, if openness to trade of the member countries of the monetary union is weak, this automatic limitation of the budgetary activism is weaker and the fiscal constraint must then be stronger.

The situation is a little bit more complex if the member countries of the monetary union have a fiscal rule in terms of public debt $\left(\alpha_{g, s}=0\right.$ and $\left.\alpha_{g, d}>0\right)$. Optimal budgetary policies should then be expansionary. Indeed, a symmetric demand shock already reduces the global budgetary deficit and the public debt. Therefore, in order to compensate for these consequences of the shock, budgetary policies can be 
expansionary in order to stabilize the public debt. Indeed, according to the values in Appendix B, we have

$$
\begin{aligned}
& \left(\operatorname{def}_{s i, t}+\operatorname{def}_{s j, t}\right)^{\text {coop }} \\
& \quad=\frac{4 \sigma\left(\tau_{t}+k\right)}{(1+k-k \sigma)\left[2 \sigma+(1-\sigma)\left(d_{i, t-1}+d_{j, t-1}\right)\right]} \varepsilon_{t}^{d} .
\end{aligned}
$$

On the contrary, noncooperative budgetary policies are contractionary in case of symmetric demand shocks in order to compensate for the expansionary and inflationary consequences of the shock. Indeed, according to the values mentioned in Appendix B, we have

$$
\left(\operatorname{def}_{s i, t}+\operatorname{def}_{s j, t}\right)^{\mathrm{nc}}=m_{\operatorname{def} s, \varepsilon_{t}^{d}} \varepsilon_{t}^{d}, \quad m_{\operatorname{def} s, \varepsilon_{t}^{d}}<0 .
$$

So, in this framework, noncooperative budgetary policies are not only excessively active but also counterproductive. Indeed, expansionary budgetary policies accentuate the increase in the indebtedness level in case of a negative demand shock, whereas contractionary budgetary policies accentuate the decrease in the indebtedness level in case of a positive symmetric demand shock. However, this excessive budgetary activism in a noncooperative framework can be reduced thanks to a penalty on the excessive public debt level. Indeed, according to the values given in Appendix B, we obtain

$$
\operatorname{Min}\left\{\frac{\partial\left[\partial\left(L_{t}^{\mathrm{nc}}-L_{t}^{\mathrm{coop}}\right) / \partial \varepsilon_{t}^{d 2}\right]}{\partial \alpha_{g, d}}\right\}=\operatorname{Min}\{|Q R|\} .
$$

According to the precise values of these parameters given in Appendix C, the parameter $(Q)$ is negative while $(R)$ is positive, besides $|Q|$ and $(R)$ are both decreasing functions of $\left(\alpha_{g, d}\right)$. Therefore, the fiscal penalty on the excessive public debt level should be as high as possible in order to constrain the excessively contractionary (expansionary) noncooperative budgetary policies in case of a positive (negative) symmetric demand shock and to make them closer to the optimal cooperative budgetary policies, to the opposite and optimal cooperative budgetary policies.

Nevertheless, in case of a symmetric demand shock, a fiscal penalty on the public debt level $\left(\alpha_{g, d}\right)$ seems less efficient than a penalty on the structural budgetary deficit. Indeed, the expression which must be minimized in (34) is higher than the expression in (31), according to the basic calibration of our parameters. As previously mentioned, the fiscal penalty should be a decreasing function of the parameters $(\sigma),(\eta)$, $(k)$, and $(v)$. Furthermore, a fiscal penalty on the public debt level should also be a decreasing function of the previous public debt levels $\left(d_{i, t-1}\right)$ and $\left(d_{j, t-1}\right)$, as high indebtedness levels make such a penalty more efficient in order to constrain the budgetary activism. This penalty should also rise with the taxation rates $\left(\tau_{t}\right)$, which increase the weight of the public sector and the budgetary activism.

\section{Conclusion}

Monetary unification creates new fiscal externalities, which can justify the introduction of fiscal rules and the attention paid to the respect for budgetary discipline, in the member countries of a monetary union. Besides, beyond traditional arguments mentioned for the introduction of such fiscal rules and penalties in a monetary union, the aim of the current paper is to play a part in the analysis on their potential contribution to a kind of indirect budgetary coordination. Indeed, as formal and explicit coordination between budgetary policies is quite minimal in Europe in the context of the EMU, appropriate fiscal penalties could be a kind of substitute to a formal coordination of budgetary policies, in such a monetary union. Thanks to appropriate fiscal penalties, the noncooperative and decentralized equilibrium could get closer to the optimal and first-best equilibrium where the budgetary authorities cooperate.

In this framework, our dynamic macroeconomic modeling shows that if the governments have a goal in terms of structural budgetary deficit, in "normal times" and without macroeconomic shocks, whatever positive penalty on the deviation of the effective structural budgetary deficit in comparison with its targeted level is optimal. But if the governments have a goal in terms of public debt, this goal cannot be reached automatically by the control variable (variation in the structural budgetary deficit) in a noncooperative framework if the public debt levels were initially distinct between the member countries of the monetary union. Indeed, noncooperative budgetary policies can then be insufficiently contractionary to decrease public debt levels which were initially excessively high. An optimal penalty on the excessive public debt level can then allow to reach the cooperative equilibrium, a penalty which must be an increasing function of the share of public consumption in GDP, of taxation rates and of the differential in indebtedness levels, but a decreasing function of the openness to trade, of price flexibility, and of the strength of automatic stabilizers in the member countries of the monetary union.

Furthermore, in case of symmetric supply shocks, budgetary policies should not react, as they have no consequences on average economic variables. However, a positive symmetric supply shock implies deflationary tensions in all member countries of the monetary union. So, a given country could be tempted to conduct a noncooperative expansionary budgetary policy in order to stabilize prices. In the same way, in case of a positive symmetric demand shock, budgetary policies should not react with a goal in terms of structural budgetary deficit, and they should even be expansionary in order to compensate for the automatic consequences of the shock with a goal in terms of public debt. However, noncooperative budgetary policies are then contractionary in order to compensate for the expansionary and inflationary consequences of the shock, even if such policies are useless if all member countries of the monetary union conduct the same policies. Therefore, in case of symmetric shocks, whatever the fiscal rule, the penalty on the excessive level of one fiscal variable in comparison with its targeted level should be as high as possible in order to constrain the excessively active noncooperative budgetary policies and to make them closer to the inactive optimal budgetary policies. Besides, a fiscal penalty on the public debt level seems more efficient to constrain the budgetary activism in case of symmetric 
supply shocks and if public debt levels were initially high, whereas a penalty on the structural budgetary deficit seems more efficient in case of symmetric demand shocks. In case of symmetric shocks, fiscal penalties should also always increase with the weight of the public sector in GDP and with taxation rates, whereas they should decrease with openness to trade and automatic stabilizers in the monetary union.

Finally, budgetary policies should be inactive on average and exactly the opposite in the member countries of a monetary union in case of asymmetric demand or supply shocks. This optimal solution is obtained without fiscal penalty with a goal in terms of structural budgetary deficit. However, budgetary activism tends to increase with the differential between the public indebtedness levels of the member countries of the monetary union. In this framework, in case of asymmetric shocks, the optimal equilibrium can be reached thanks to a moderate penalty on the excessive public debt level only if the share of the private sector in GDP, openness to trade, and price flexibility are sufficiently high, whereas on the contrary automatic stabilizers, taxation rates, and indebtedness levels are sufficiently weak in the member countries of the monetary union. In the opposite case, a fiscal penalty on the excessive public debt level could only decrease the budgetary activism, without reaching the optimal and cooperative equilibrium where the average structural budgetary deficit is zero.

So, fiscal penalties on the excessive structural budgetary deficit or on the excessive public debt level are beneficial. They can contribute to reduce an inefficient budgetary activism and to a kind of indirect coordination between the budgetary policies of the member countries of a monetary union. Indeed, budgetary policies are then less active and closer to the optimal cooperative equilibrium. With the values that we propose, there is no longer a problem of credibility and cooperation between the budgetary authorities, as optimal policies can be enforced thanks to fiscal penalties in the framework of decentralized and noncooperative budgetary policies. Nevertheless, optimal fiscal penalties seem quite difficult to define for the governments, as they depend on the nature of the macroeconomic shocks in the framework of our model. Therefore, another trade-off appears between the efficiency of the optimal fiscal rule and its degree of complexity. Perhaps fiscal rules which are less efficient but easier to implement and to enforce would be more beneficial. That is why the fiscal compact has defined a state-independent and simple fiscal contract for the European countries, which is quite easy to implement, even if it is not fully optimal from a theoretical point of view.

\section{Appendices}

\section{A. Economic Activity and Inflation Rate Equations}

By combining (1) and (6), we obtain

$$
\begin{aligned}
(1 & +k-k \sigma) y_{i, t}^{d} \\
& =(1+k-k \sigma) y_{i, t+1}^{e}+(1-\sigma)\left(\tau_{t}^{*}+k\right) y_{i, t}^{*}
\end{aligned}
$$

$$
\begin{aligned}
& -(1-\sigma)\left(\tau_{t+1}^{* e}+k\right) y_{i, t+1}^{* e}+\eta\left(\pi_{j, t}-\pi_{i, t}\right) \\
& -\sigma\left(i_{t}-\pi_{i, t+1}^{e}-r_{i, t}^{*}\right)+(1-\sigma)\left(\operatorname{def}_{s i, t}-\operatorname{def}_{s i, t+1}^{e}\right)+\varepsilon_{i, t}^{d}
\end{aligned}
$$

Solving (A.1) and (7) forwards, and under the assumption that $\lim _{T \rightarrow \infty} y_{i, t+T}=\lim _{T \rightarrow \infty} y_{i, t+T}^{*}=\lim _{T \rightarrow \infty} \operatorname{def}_{s i, t+T}=$ $\lim _{T \rightarrow \infty} \pi_{i, t+T}=0$, we have

$$
\begin{gathered}
(1+k-k \sigma) y_{i, t}^{d} \\
=(1-\sigma)\left(\tau_{t}^{*}+k\right) y_{i, t}^{*}-\sigma\left(i_{t}-r_{i, t}^{*}\right) \\
\quad-\sigma \sum_{T=0}^{\infty}\left(i_{t+T+1}^{e}-\pi_{i, t+T+2}^{e}-r_{i, t+T+1}^{* e}\right) \\
+\eta\left(\pi_{j, t}-\pi_{i, t}\right)+\eta \sum_{T=0}^{\infty}\left(\pi_{j, t+T+1}^{e}-\pi_{i, t+T+1}^{e}\right) \\
+\sigma \pi_{i, t+1}^{e}+(1-\sigma) \operatorname{def}_{s i, t}+\varepsilon_{i, t}^{d}, \\
v\left(y_{i, t}-y_{i, t}^{*}\right) \\
+v \sum_{i, t}^{\infty} b^{T+1}\left(y_{i, t+T+1}^{e}-y_{i, t+T+1}^{* e}\right)-\varepsilon_{i, t}^{s} .
\end{gathered}
$$

Then, by combining (A.2) and (A.3) and assuming that future errors of anticipations on economic activity levels, inflation rates, or real interest rates will cancel on average, we obtain

$$
\begin{aligned}
(1+ & k-k \sigma)(1+k-k \sigma+2 v \eta) \pi_{i, t} \\
= & -v \sigma(1+k-\sigma k+2 v \eta) i_{t} \\
& +v(1+k-k \sigma+v \eta)\left[(1-\sigma) \operatorname{def}_{s i, t}+\varepsilon_{i, t}^{d}\right] \\
& +v^{2} \eta\left[(1-\sigma) \operatorname{def}_{s j, t}+\varepsilon_{j, t}^{d}\right] \\
& -(1+k-k \sigma)(1+k-k \sigma+v \eta) \varepsilon_{i, t}^{s} \\
& -v \eta(1+k-k \sigma) \varepsilon_{j, t}^{s}+f\left(y_{i, t}^{*}, y_{j, t}^{*}, r_{i, t}^{*}, r_{j, t}^{*}\right) .
\end{aligned}
$$

On average for the whole monetary union, we have

$$
\begin{aligned}
(1+k-k \sigma) \pi_{t}= & v(1-\sigma) \operatorname{def}_{s, t}-v \sigma i_{t}+v \varepsilon_{t}^{d} \\
& -(1+k-k \sigma) \varepsilon_{t}^{s}+f\left(y_{i, t}^{*}, y_{j, t}^{*}, r_{i, t}^{*}, r_{j, t}^{*}\right) .
\end{aligned}
$$

So, if expected demand and supply shocks equal zero, and if the monetary authority aims at stabilizing average prices in the monetary union $\left(\pi_{t}=0\right)$, the interest rate is fixed at the following level:

$$
\sigma i_{t}=(1-\sigma) \operatorname{def}_{s, t}+f\left(y_{i, t}^{*}, y_{j, t}^{*}, r_{i, t}^{*}, r_{j, t}^{*}\right) .
$$

We can replace this value of $\left(i_{t}\right)$ in (A.4) in order to obtain the inflation rate in the country $(i)$. Afterwards, we can replace this value of $\left(\pi_{i, t}\right)$ in (A.2) in order to obtain the economic activity level $\left(y_{i, t}\right)$. 


\section{B. Excessive Loss in Absence of Cooperation between the Budgetary Authorities}

Without budgetary cooperation, using (9), (10), (11), and (12), $\partial L_{i, t} / \partial\left(\operatorname{def}_{s i, t}\right)=0$ implies

$$
\begin{aligned}
& \left(\operatorname{def}_{s i, t}+\operatorname{def}_{s j, t}\right)^{\mathrm{nc}} \\
& =m_{\mathrm{def} s, \varepsilon_{t}^{d}} \varepsilon_{t}^{d}+m_{\mathrm{def} s, \overline{\varepsilon_{t}^{d}}} \overline{\varepsilon_{t}^{d}}+m_{\mathrm{def} s, \varepsilon_{t}^{s}} \varepsilon_{t}^{s}+m_{\mathrm{def} s, \overline{\varepsilon_{t}^{s}}} \overline{\varepsilon_{t}^{s}} \\
& +m_{\operatorname{def} s, \operatorname{def} s T} \operatorname{def}_{s}^{T}+m_{\operatorname{def} s, d i T}\left(d_{i, t-1}-d^{T}\right) \\
& +m_{\mathrm{def} s, d j T}\left(d_{j, t-1}-d^{T}\right)+f\left(y_{i, t}^{*}, y_{j, t}^{*}, r_{i, t}^{*}, r_{j, t}^{*}\right), \\
& \Delta_{\text {def } s}=\left[\alpha_{\pi} m_{\pi i, \text { def } s i}^{2}+\alpha_{y} m_{y i, \operatorname{def} s i}^{2}\right] \\
& \times\left[2 \alpha_{g, s}+\alpha_{g, d}\right. \\
& \times\left(m_{d j, \mathrm{def} s j}^{2}+m_{d i, \mathrm{def} s i}^{2}\right. \\
& \left.\left.+m_{d j, \text { def } s j} m_{d j, \text { def } s i}+m_{d i, \operatorname{def} s i} m_{d i, \operatorname{def} s j}\right)\right] \\
& +\alpha_{g, s}\left[\alpha_{g, s}+\alpha_{g, d}\left(m_{d i, \operatorname{def} s i}^{2}+m_{d j, \operatorname{def} s j}^{2}\right)\right] \\
& +\alpha_{g, d}^{2} m_{d i, \mathrm{def} s i} m_{d j, \mathrm{def} s j}\left(m_{d i, \mathrm{def} s i}+m_{d j, \mathrm{def} s i}\right) \\
& \times\left(m_{d i, \operatorname{def} s i}-m_{d i, \operatorname{def} s j}\right), \\
& m_{\mathrm{def} s, \varepsilon_{t}^{d}} \\
& =-\left\{\left(\alpha_{\pi} m_{\pi i \text {,ef } s i} m_{\pi i, \varepsilon_{t}^{d}}+\alpha_{y} m_{y i, \operatorname{def} s i} m_{y i, \varepsilon_{t}^{d}}\right)\right. \\
& \times\left[4 \alpha_{\pi} m_{\pi i, \mathrm{def} s i}^{2}+4 \alpha_{y} m_{y i, \mathrm{def} s i}^{2}+2 \alpha_{g, s}+\alpha_{g, d}\right. \\
& \times\left(m_{d i, \mathrm{def} s i}+m_{d j, \mathrm{def} s j}\right) \\
& \left.\times\left(m_{d i, \mathrm{def} s i}-m_{d i, \mathrm{def} s j}\right)\right]+\alpha_{g, d} m_{d i, \varepsilon_{t}^{d}} \\
& \times\left[\alpha_{g, s}\left(m_{d i, \operatorname{def} s i}+m_{d j, \operatorname{def} s j}\right)+2 \alpha_{g, d}\right. \\
& \left.\times\left(m_{d i, \operatorname{def} s i}-m_{d i, \operatorname{def} s j}\right) m_{d i, \operatorname{def} s i} m_{d j, \operatorname{def} s j}\right] \\
& +2 \alpha_{g, d}\left(m_{d i, \operatorname{def} s i}+m_{d j, \operatorname{def} s j}\right) m_{d i, \varepsilon_{t}^{d}} \\
& \left.\times\left(\alpha_{\pi} m_{\pi i, \mathrm{def} s i}^{2}+\alpha_{y} m_{y i, \mathrm{def} s i}^{2}\right)\right\} \\
& \times\left(\Delta_{\text {def } s}\right)^{-1} \text {, } \\
& m_{\text {def } s, \overline{\varepsilon_{t}^{d}}} \\
& =\left(\alpha _ { g , d } \left\{m_{d_{i}, \overline{\varepsilon_{t}^{d}}}\right.\right. \\
& \times\left[\alpha_{g, s}\left(m_{d j, \operatorname{def} s j}-m_{d i, \operatorname{def} s i}\right)\right. \\
& +\alpha_{g, d} m_{d i, \text { def } s i}^{2}\left(m_{d j, \operatorname{def} s j}-m_{d i, \text { def } s j}\right) \\
& \left.-\alpha_{g, d} m_{d j, \mathrm{def} s j}^{2}\left(m_{d i, \mathrm{def} s i}-m_{d j, \mathrm{def} s i}\right)\right] \\
& +\left(m_{d i, \text { def } s i}-m_{d i, \operatorname{def} s j}\right)
\end{aligned}
$$

$$
\begin{aligned}
& \times\left(\alpha_{\pi} m_{\pi i \text {,def } s i} m_{\pi_{i}, \overline{\varepsilon_{t}^{d}}}+\alpha_{y} m_{y i \text {,def } s i} m_{y_{i}, \overline{\varepsilon_{t}^{d}}}\right) \\
& \left.\left.\times\left(m_{d i, \mathrm{def} s i}-m_{d j, \mathrm{def} s j}\right)\right\}\right) \\
& \times\left(\Delta_{\operatorname{def} s}\right)^{-1}, \\
& m_{\text {def } s, \varepsilon_{t}^{s}} \\
& =\left(-\alpha_{\pi} m_{\pi i, \mathrm{def} s i} m_{\pi i, \varepsilon_{t}^{s}}\right. \\
& \times\left[4 \alpha_{\pi} m_{\pi i, \mathrm{def} s i}^{2}+4 \alpha_{y} m_{y i \text {,ef } s i}^{2}+2 \alpha_{g, s}+\alpha_{g, d}\right. \\
& \times\left(m_{d i, \text { def } s i}^{2}-m_{d j, \operatorname{def} s j} m_{d j, \text { def } s i}\right. \\
& \left.\left.\left.+m_{d j \text {,def } s j}^{2}-m_{d i, \text { def } s i} m_{d i, \text { def } s j}\right)\right]\right) \\
& \times\left(\Delta_{\operatorname{def} s}\right)^{-1}, \\
& m_{\operatorname{def} s, \overline{\varepsilon_{t}^{s}}} \\
& =\left(\alpha _ { g , d } \left\{m_{d_{i}, \overline{\varepsilon_{t}^{s}}}\right.\right. \\
& \times\left[\alpha_{g, s}\left(m_{d j, \mathrm{def} s j}-m_{d i, \mathrm{def} s i}\right)\right. \\
& +\alpha_{g, d} m_{d i, \mathrm{def} s i}^{2}\left(m_{d j, \mathrm{def} s j}-m_{d i, \mathrm{def} s j}\right) \\
& \left.-\alpha_{g, d} m_{d j, \text { def } s j}^{2}\left(m_{d i, \text { def } s i}-m_{d j, \text { def } s i}\right)\right] \\
& +\left(m_{d i, \text { def } s i}-m_{d i, \text { def } s j}\right) \\
& \times\left(\alpha_{\pi} m_{\pi i \text {,ef } s i} m_{\pi_{i}, \overline{\varepsilon_{t}^{s}}}+\alpha_{y} m_{y i, \mathrm{def} s i} m_{y_{i}, \overline{\varepsilon_{t}^{s}}}\right) \\
& \left.\left.\times\left(m_{d i, \operatorname{def} s i}-m_{d j, \operatorname{def} s j}\right)\right\}\right) \\
& \times\left(\Delta_{\text {def } s}\right)^{-1}, \\
& m_{\operatorname{def} s, \operatorname{def} s T} \\
& =\left(\alpha _ { g , s } \left[4 \alpha_{\pi} m_{\pi i, \mathrm{def} s i}^{2}+4 \alpha_{y} m_{y i, \mathrm{def} s i}^{2}+2 \alpha_{g, s}\right.\right. \\
& +\alpha_{g, d}\left(m_{d i, \mathrm{def} s i}-m_{d i, \mathrm{def} s j}\right) \\
& \left.\left.\times\left(m_{d i, \mathrm{def} s i}+m_{d j, \mathrm{def} s j}\right)\right]\right) \\
& \times\left(\Delta_{\operatorname{def} s}\right)^{-1}, \\
& m_{\text {def } s, d i T}=\left(-\alpha_{g, d} m_{d i, \text { def } s i}\right. \\
& \times\left[2 \alpha_{\pi} m_{\pi i, \mathrm{def} s i}^{2}+2 \alpha_{y} m_{y i \text {,ef } s i}^{2}+\alpha_{g, s}\right. \\
& \left.\left.+\alpha_{g, d} m_{d j, \operatorname{def} s j}\left(m_{d j, \operatorname{def} s j}-m_{d j, \operatorname{def} s i}\right)\right]\right) \\
& \times\left(\Delta_{\text {def } s}\right)^{-1} \text {. }
\end{aligned}
$$

The optimal solution is the one that minimizes average variables in a cooperative framework. Consider

$$
\begin{aligned}
L_{t}=\frac{1}{2}[ & \alpha_{\pi} \pi_{t}^{2}+\alpha_{y}\left(y_{t}-y_{t}^{*}\right)^{2} \\
& \left.\quad+\alpha_{g, s}\left(\operatorname{def}_{s, t}-\operatorname{def}_{s}^{T}\right)^{2}+\alpha_{g, d}\left(d_{t}-d^{T}\right)^{2}\right] .
\end{aligned}
$$


However, $\left(\pi_{t}\right)$ and $\left(y_{t}\right)$ only depend on the differential in budgetary policies; so

$$
\begin{aligned}
\frac{\partial L_{t}}{\partial\left(\operatorname{def}_{s i, t}\right)}= & \alpha_{g, s} \frac{\partial \operatorname{def}_{s, t}}{\partial\left(\operatorname{def}_{s i, t}\right)}\left(\operatorname{def}_{s, t}-\operatorname{def}_{s}^{T}\right) \\
& +\alpha_{g, d} \frac{\partial d_{t}}{\partial\left(\operatorname{def}_{s i, t}\right)}\left(d_{t}-d^{T}\right)=0 .
\end{aligned}
$$

Besides, (12) implies

$$
\begin{aligned}
4 \sigma\left(d_{t}-d^{T}\right) \\
=\left[2 \sigma+(1-\sigma)\left(d_{i, t-1}+d_{j, t-1}\right)\right]\left(\operatorname{def}_{s i, t}+\operatorname{def}_{s j, t}\right) \\
\quad-4 \sigma \frac{\left(\tau_{t}+k\right)}{(1+k-k \sigma)} \varepsilon_{t}^{d}+2 \sigma\left(d_{i, t-1}+d_{j, t-1}-2 d^{T}\right) \\
\quad+f\left(y_{i, t}^{*}, y_{j, t}^{*}, r_{i, t}^{*}, r_{j, t}^{*}\right) .
\end{aligned}
$$

So, we obtain

$$
\begin{aligned}
& \left\{4 \sigma^{2} \alpha_{g, s}+\alpha_{g, d}\left[2 \sigma+(1-\sigma)\left(d_{i, t-1}+d_{j, t-1}\right)\right]^{2}\right\} \\
& \quad \times\left(\operatorname{def}_{s i, t}+\operatorname{def}_{s j, t}\right)^{\text {coop }} \\
& =8 \alpha_{g, s} \sigma^{2} \operatorname{def}_{s}^{T}-2 \sigma \alpha_{g, d}\left[2 \sigma+(1-\sigma)\left(d_{i, t-1}+d_{j, t-1}\right)\right] \\
& \quad \times\left(d_{i, t-1}+d_{j, t-1}-2 d^{T}\right) \\
& \quad+4 \sigma \alpha_{g, d}\left[2 \sigma+(1-\sigma)\left(d_{i, t-1}+d_{j, t-1}\right)\right] \\
& \quad \times \frac{\left(\tau_{t}+k\right)}{(1+k-k \sigma)} \varepsilon_{t}^{d}+f\left(y_{i, t}^{*}, y_{j, t}^{*}, r_{i, t}^{*}, r_{j, t}^{*}\right) .
\end{aligned}
$$

Therefore, if we suppose that all shocks and targets are independent, the differential between the noncooperative and cooperative loss functions implies

$$
\begin{aligned}
& 4 \sigma^{2}\left\{4 \alpha_{g, s} \sigma^{2}+\alpha_{g, d}\left[2 \sigma+(1-\sigma)\left(d_{i, t-1}+d_{j, t-1}\right)\right]^{2}\right\} \\
& \times\left(L_{t}^{\mathrm{nc}}-L_{t}^{\text {coop }}\right) \\
& =\frac{1}{8}\left\{4 \alpha_{g, s} \sigma^{2} m_{\operatorname{def} s, \varepsilon_{t}^{d}}+\alpha_{g, d}\left[2 \sigma+(1-\sigma)\left(d_{i, t-1}+d_{j, t-1}\right)\right]\right. \\
& \times\left[2 \sigma m_{\operatorname{def} s, \varepsilon_{t}^{d}}+(1-\sigma)\left(d_{i, t-1}+d_{j, t-1}\right)\right. \\
& \left.\left.\quad \times m_{\text {def } s, \varepsilon_{t}^{d}}-4 \sigma \frac{\left(\tau_{t}+k\right)}{(1+k-k \sigma)}\right]\right\}^{2} \varepsilon_{t}^{d 2} \\
& +\frac{1}{8} \alpha_{g, d}\left\{4 \sigma^{2} \alpha_{g, s}+\alpha_{g, d}\left[2 \sigma+(1-\sigma)\left(d_{i, t-1}+d_{j, t-1}\right)\right]^{2}\right\} \\
& \times\left\{4 \sigma^{2}+\left[2 \sigma+(1-\sigma)\left(d_{i, t-1}+d_{j, t-1}\right)\right]^{2}\right\}
\end{aligned}
$$

$$
\begin{aligned}
& \times\left(m_{\text {def } s, \bar{\varepsilon}_{t}^{d}}^{2} \overline{\varepsilon_{t}^{d 2}}+m_{\operatorname{def} s, \overline{\varepsilon_{t}^{s}}}^{2} \overline{\mathcal{\varepsilon}_{t}^{2}}\right) \\
& +\frac{1}{8}\left\{4 \sigma^{2} \alpha_{g, s}+\alpha_{g, d}\left[2 \sigma+(1-\sigma)\left(d_{i, t-1}+d_{j, t-1}\right)\right]^{2}\right\}^{2} \\
& \times m_{\mathrm{def} s, \varepsilon_{t}^{2}}^{2} \varepsilon_{t}^{s 2} \\
& +\frac{1}{8}\left\{4 \sigma^{2} \alpha_{g, s}\left(m_{\operatorname{def} s, \operatorname{def} s T}-2\right)\right. \\
& \left.+\alpha_{g, d}\left[2 \sigma+(1-\sigma)\left(d_{i, t-1}+d_{j, t-1}\right)\right]^{2} m_{\operatorname{def} s, \operatorname{def} s T}\right\}^{2} \\
& \times \operatorname{def}_{s}^{T 2}+\frac{1}{8}\left\{4 \alpha_{g, s} \sigma^{2} m_{\operatorname{def} s, d i T}\right. \\
& +\alpha_{g, d}\left[2 \sigma+(1-\sigma)\left(d_{i, t-1}+d_{j, t-1}\right)\right] \\
& \times\left[2 \sigma+2 \sigma m_{\mathrm{def} s, d i T}+m_{\mathrm{def} s, d i T}(1-\sigma)\right. \\
& \left.\left.\times\left(d_{i, t-1}+d_{j, t-1}\right)\right]\right\}^{2}\left(d_{i, t-1}-d^{T}\right)^{2} \\
& +\frac{1}{8}\left\{4 \alpha_{g, s} \sigma^{2} m_{\text {def } s, d j T}\right. \\
& +\alpha_{g, d}\left[2 \sigma+(1-\sigma)\left(d_{i, t-1}+d_{j, t-1}\right)\right] \\
& \times\left[2 \sigma+2 \sigma m_{\mathrm{def} s, d j T}\right. \\
& \left.\left.+m_{\operatorname{def} s, d j T}(1-\sigma)\left(d_{i, t-1}+d_{j, t-1}\right)\right]\right\}^{2} \\
& \times\left(d_{j, t-1}-d^{T}\right)^{2}-4 \sigma^{4} \alpha_{g, s} \alpha_{g, d}\left(d_{i, t-1}-d^{T}\right) \\
& \times\left(d_{j, t-1}-d^{T}\right)+f\left(y_{i, t}^{*}, y_{j, t}^{*}, r_{i, t}^{*}, r_{j, t}^{*}\right) \text {. }
\end{aligned}
$$

\section{Specific Parameters}

Consider

$$
\begin{aligned}
& P=\left(1-\tau_{t}+\sigma \tau_{t}+2 v \eta\right)^{2}\left(m_{d i, \mathrm{def} s i}+m_{d j, \mathrm{def} s j}\right) \\
& \times\left[2 \sigma+(1-\sigma)\left(d_{i, t-1}+d_{j, t-1}\right)\right] \\
&+\frac{(1-\sigma)^{2}\left(1-\tau_{t}+\sigma \tau_{t}+2 v \eta\right)}{2 \alpha_{g, d}(1+k-k \sigma+2 v \eta)} \\
& \times\left(\alpha_{\pi} v^{2}+\alpha_{y}\right)\left[10 \sigma+5(1-\sigma)\left(d_{i, t-1}+d_{j, t-1}\right)\right.-\frac{m_{d j, \mathrm{def} s j}}{m_{d i, \mathrm{def} s i}}\left(d_{j, t-1}(1-\sigma)+\sigma\right) \\
&\left.-\frac{m_{d i, \mathrm{def} s i}}{m_{d j, \mathrm{def} s j}}\left(d_{i, t-1}(1-\sigma)+\sigma\right)\right] \\
&+\frac{(1-\sigma)^{4}\left(\alpha_{\pi} v^{2}+\alpha_{y}\right)^{2}}{2 \alpha_{g, d}^{2}(1+k-k \sigma+2 v \eta)^{2}}
\end{aligned}
$$




$$
\begin{aligned}
& \times\left[m_{d j, \operatorname{def} s j}\left(d_{j, t-1}(1-\sigma)+\sigma\right)\right. \\
& \left.+m_{d i, \operatorname{def} s i}\left(d_{i, t-1}(1-\sigma)+\sigma\right)\right]>0, \\
& Q=\left[2 \sigma+(1-\sigma)\left(d_{i, t-1}+d_{j, t-1}\right)\right] m_{\mathrm{def} s, \varepsilon_{t}^{d}}-4 \sigma \frac{\left(\tau_{t}+k\right)}{(1+k-k \sigma)} \\
& =-\frac{\alpha_{g, d}\left(\alpha_{\pi} v^{2}+\alpha_{y}\right)(1-\sigma)^{2}}{\Delta_{\text {def } s}(1+k-k \sigma)(1+k-k \sigma+2 v \eta)^{2}} \\
& \times\left\{\frac{(1-\sigma)\left[2 \sigma+(1-\sigma)\left(d_{i, t-1}+d_{j, t-1}\right)\right]}{2(1+k-k \sigma+2 v \eta)}\right. \\
& \times \frac{\left(\alpha_{\pi} v^{2}+\alpha_{y}\right)}{\alpha_{g, d}}+\left(m_{d i, \text { def } s i}+m_{d j, \text { def } s j}\right) \\
& \times \frac{\left[2 \sigma+(1-\sigma)\left(d_{i, t-1}+d_{j, t-1}\right)\right]}{2(1-\sigma)} \\
& \times\left(1-2 \tau_{t}+2 \sigma \tau_{t}-k+k \sigma+2 v \eta\right) \\
& +\left(\tau_{t}+k\right) m_{d j, \operatorname{def} s j}\left[d_{j, t-1}(1-\sigma)+\sigma\right] \\
& \left.+\left(\tau_{t}+k\right) m_{d i \text {,ef } s i}\left[d_{i, t-1}(1-\sigma)+\sigma\right]\right\}<0, \\
& R=\left[2 \sigma+(1-\sigma)\left(d_{i, t-1}+d_{j, t-1}\right)\right] \\
& \times\left[2 \alpha_{g, d} \frac{\partial m_{\mathrm{def} s, \varepsilon_{t}^{d}}}{\partial \alpha_{g, d}}+m_{\mathrm{def} s, \varepsilon_{t}^{d}}\right]-4 \sigma \frac{\left(\tau_{t}+k\right)}{(1+k-k \sigma)} \\
& =\left(\alpha_{g, d}^{3}\left(\alpha_{\pi} v^{2}+\alpha_{y}\right)(1-\sigma)^{2}\right. \\
& \left.\times\left[2 \sigma+(1-\sigma)\left(d_{i, t-1}+d_{j, t-1}\right)\right]\right) \\
& \times\left(2 \sigma \Delta_{\text {def } s}^{2}(1+k-k \sigma+2 v \eta)^{3}(1+k-k \sigma)\right)^{-1} \\
& \times\left\{\frac{(1-\sigma)^{3}\left(\alpha_{\pi} v^{2}+\alpha_{y}\right)^{2}}{4 \alpha_{g, d}^{2}(1+k-k \sigma+2 v \eta)^{2}}\right. \\
& \times\left\{m_{d j, \operatorname{def} s j}\left[d_{j, t-1}(1-\sigma)+\sigma\right]\right. \\
& \left.+m_{d i, \operatorname{def} s i}\left[d_{i, t-1}(1-\sigma)+\sigma\right]\right\} \\
& -\frac{\left(\alpha_{\pi} v^{2}+\alpha_{y}\right)(1-\sigma)}{4 \alpha_{g, d}(1+k-k \sigma+2 v \eta)} \\
& \times\left(1-2 \tau_{t}+2 \sigma \tau_{t}-k+k \sigma+2 v \eta\right) \\
& \times\left(m_{d i, \mathrm{def} s i}+m_{d j, \mathrm{def} s j}\right) \\
& \times\left\{m_{d j, \operatorname{def} s j}\left[d_{j, t-1}(1-\sigma)+\sigma\right]\right. \\
& \left.+m_{d i, \operatorname{def} s i}\left[d_{i, t-1}(1-\sigma)+\sigma\right]\right\}
\end{aligned}
$$

$$
\begin{aligned}
& -\frac{\left(\alpha_{\pi} v^{2}+\alpha_{y}\right)\left(\tau_{t}+k\right)}{2 \alpha_{g, d}\left[2 \sigma+(1-\sigma)\left(d_{i, t-1}+d_{j, t-1}\right)\right]} \\
& \times \frac{(1-\sigma)^{2}}{(1+k-k \sigma+2 v \eta)} \\
& \times\left\{m_{d j, \operatorname{def} s j}\left[d_{j, t-1}(1-\sigma)+\sigma\right]\right. \\
& \left.+m_{d i, \operatorname{def} s i}\left[d_{i, t-1}(1-\sigma)+\sigma\right]\right\}^{2} \\
& +3\left(\alpha_{\pi} v^{2}+\alpha_{y}\right) \frac{(1-\sigma)\left(1-\tau_{t}+\sigma \tau_{t}+2 v \eta\right)}{2 \alpha_{g, d}(1+k-k \sigma+2 v \eta)} \\
& \times m_{d i, \operatorname{def} s i} m_{d j, \operatorname{def} s j}\left[2 \sigma+(1-\sigma)\left(d_{i, t-1}+d_{j, t-1}\right)\right] \\
& +\left(\tau_{t}+k\right)\left(1-\tau_{t}+\sigma \tau_{t}+2 v \eta\right) m_{d i, \operatorname{def} s i} m_{d j, \operatorname{def} s j} \\
& \times\left\{m_{d j, \operatorname{def} s j}\left[d_{j, t-1}(1-\sigma)+\sigma\right]\right. \\
& \left.+m_{d i, \operatorname{def} s i}\left[d_{i, t-1}(1-\sigma)+\sigma\right]\right\} \\
& +\frac{\left(1-\tau_{t}+\sigma \tau_{t}+2 v \eta\right)}{2(1-\sigma)} \\
& \times\left(1-2 \tau_{t}+2 \sigma \tau_{t}-k+k \sigma+2 v \eta\right) \\
& \times m_{d i, \operatorname{def} s i} m_{d j, \operatorname{def} s j}\left(m_{d i, \operatorname{def} s i}+m_{d j, \operatorname{def} s j}\right) \\
& \left.\times\left[2 \sigma+(1-\sigma)\left(d_{i, t-1}+d_{j, t-1}\right)\right]\right\}>0 .
\end{aligned}
$$

\section{Conflict of Interests}

The author declares that there is no conflict of interests regarding the publication of this paper.

\section{References}

[1] M. Buti and D. Franco, Fiscal Policy in Economic and Monetary Union: Theory, Evidence and Institutions, Edward Elgar, 2005.

[2] T. D. Lane, "Market discipline," IMF Staff Papers, vol. 40, pp. 53-88, 1993.

[3] European Commission, "Public finance in EMU," European Economy, vol. 3, 2011.

[4] European Central Bank, "A fiscal compact for a stronger economic and monetary union," ECB Monthly Bulletin, pp. 7994, 2012.

[5] R. Tamborini, "The new rules of the Stability and Growth Pact. Threats from heterogeneity and interdependence," University of Trento, no. 4, Working paper, 2011.

[6] F. Fabbrini, "The Fiscal Compact, the "Golden Rule", and the paradox of European federalism," Boston College International and Comparative Law Review, vol. 36, no. 1, article 1, 2013.

[7] M. J. Artis and M. Buti, '“Close-to-balance or in surplus': a policy-maker's guide to the implementation of the stability and growth pact," Journal of Common Market Studies, vol. 38, no. 4, pp. 563-591, 2000. 
[8] P. Villieu, "Quelle gouvernance pour une Union monétaire asymétrique? Un modèle simple," Brussels Economic Review, vol. 51, no. 1, pp. 57-78, 2008.

[9] M. Buti, D. Franco, and H. Ongena, "Fiscal discipline and flexibility in EMU: the implementation of the stability and growth pact," Oxford Review of Economic Policy, vol. 14, no. 3, pp. 81-97, 1998.

[10] F. O. Bilbiie and D. Stasavage, "Incomplete fiscal rules with imperfect enforcement," European University Institute and London School of Economics, 2003.

[11] H. Jensen, "Optimal monetary policy cooperation through state-independent contracts with targets," European Economic Review, vol. 44, no. 3, pp. 517-539, 2000.

[12] P. Manasse, "Deficit limits and fiscal rules for dummies," IMF Working Paper, vol. 120, no. 5, 2005.

[13] A. Hughes Hallett, "Debt targets and fiscal sustainability in an era of monetary independence," International Economics and Economic Policy, vol. 5, no. 1-2, pp. 165-187, 2008.

[14] R. Beetsma and H. Jensen, "Contingent deficit sanctions and moral hazard with a stability pact," Journal of International Economics, vol. 61, no. 1, pp. 187-208, 2003.

[15] P. Villieu, "Pacte de Stabilité, crédibilité du policy-mix et coordination des politiques budgétaires en union monétaire," Revue Economique, vol. 54, no. 1, pp. 25-46, 2003.

[16] L. Schuknecht, "EU fiscal rules. Issues and lessons from political economy," ECB Working Paper Series, no. 421, 2004.

[17] L. Lieb, "Taking real wage rigidities seriously: implications for optimal policy design in a currency union," International Economic Journal, vol. 26, no. 1, pp. 37-68, 2012.

[18] J. Galí and T. Monacelli, "Optimal monetary and fiscal policy in a currency union," Journal of International Economics, vol. 76, no. 1, pp. 116-132, 2008. 

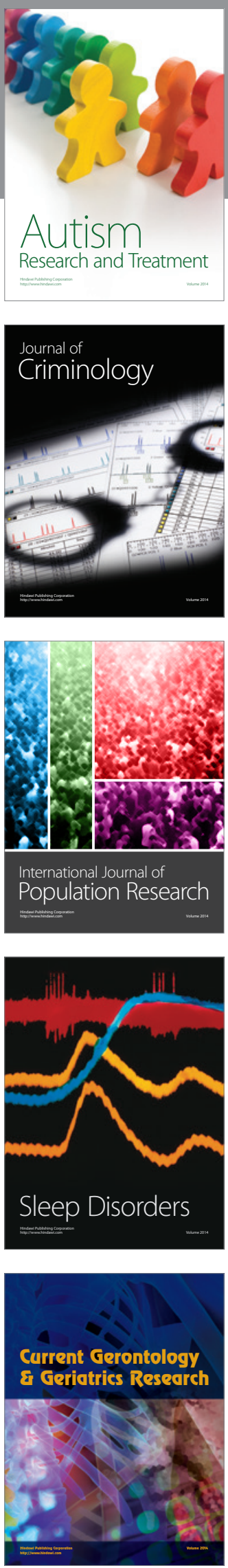
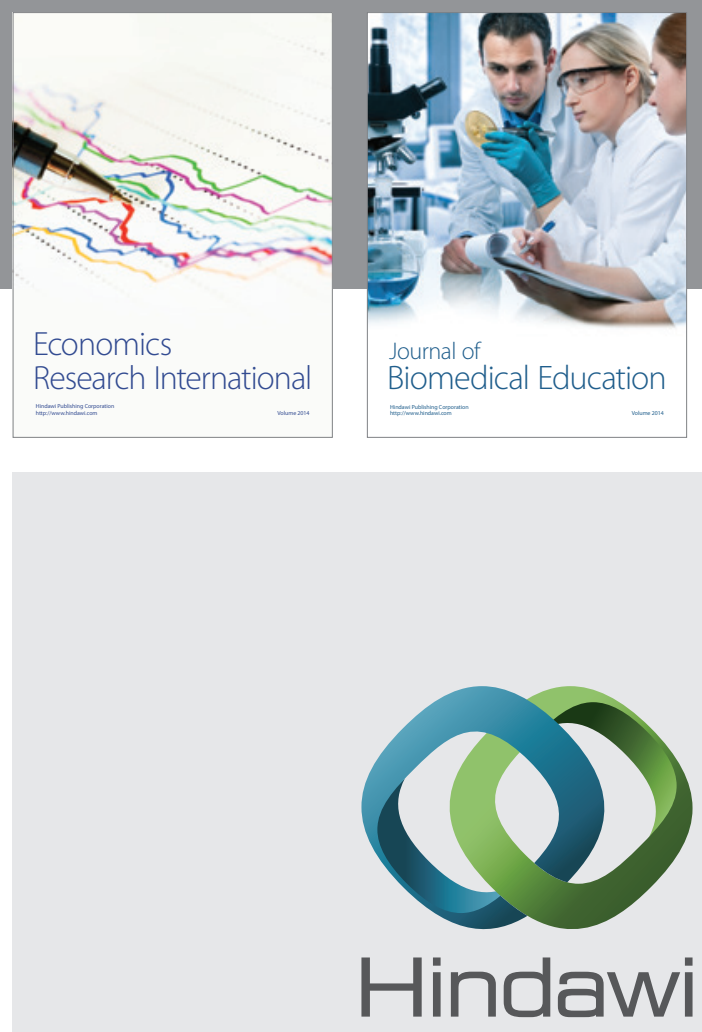

Submit your manuscripts at

http://www.hindawi.com
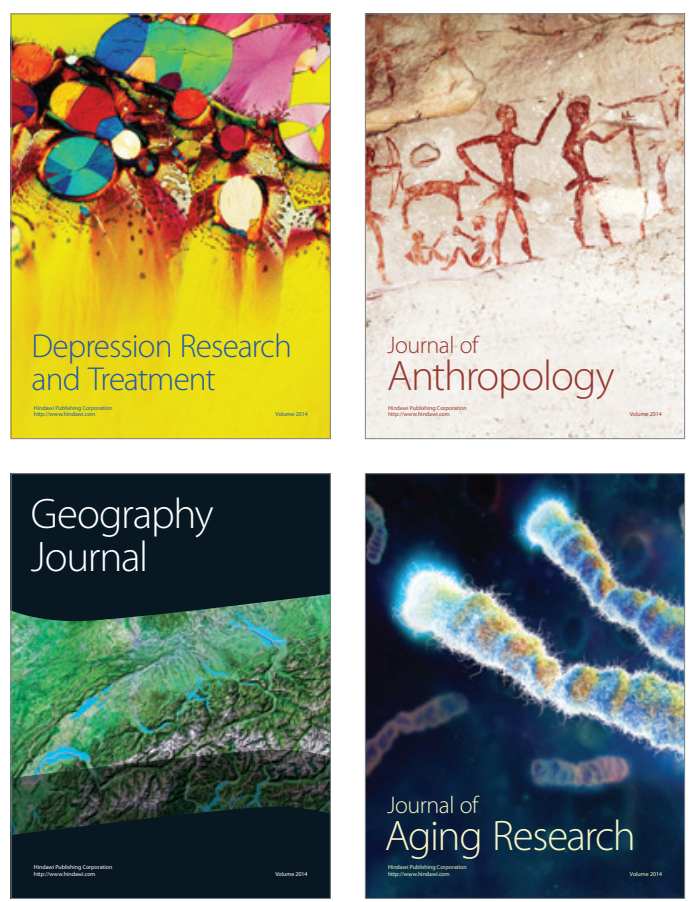
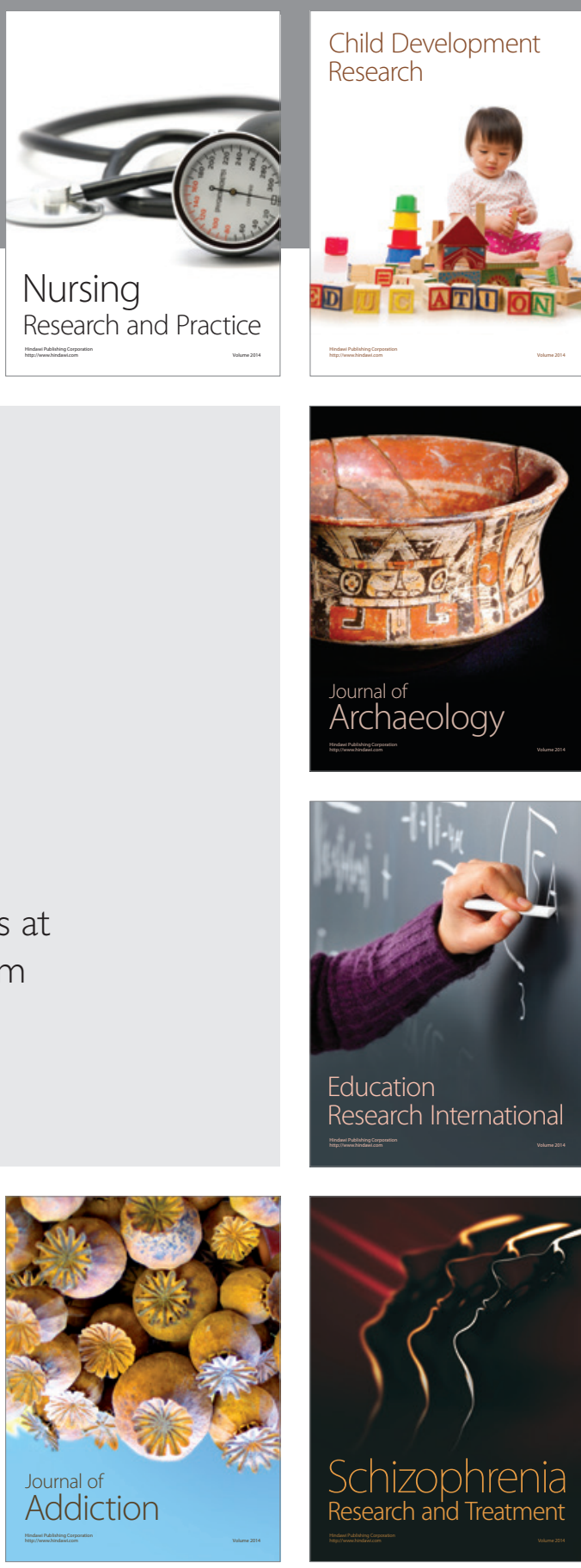

(D)
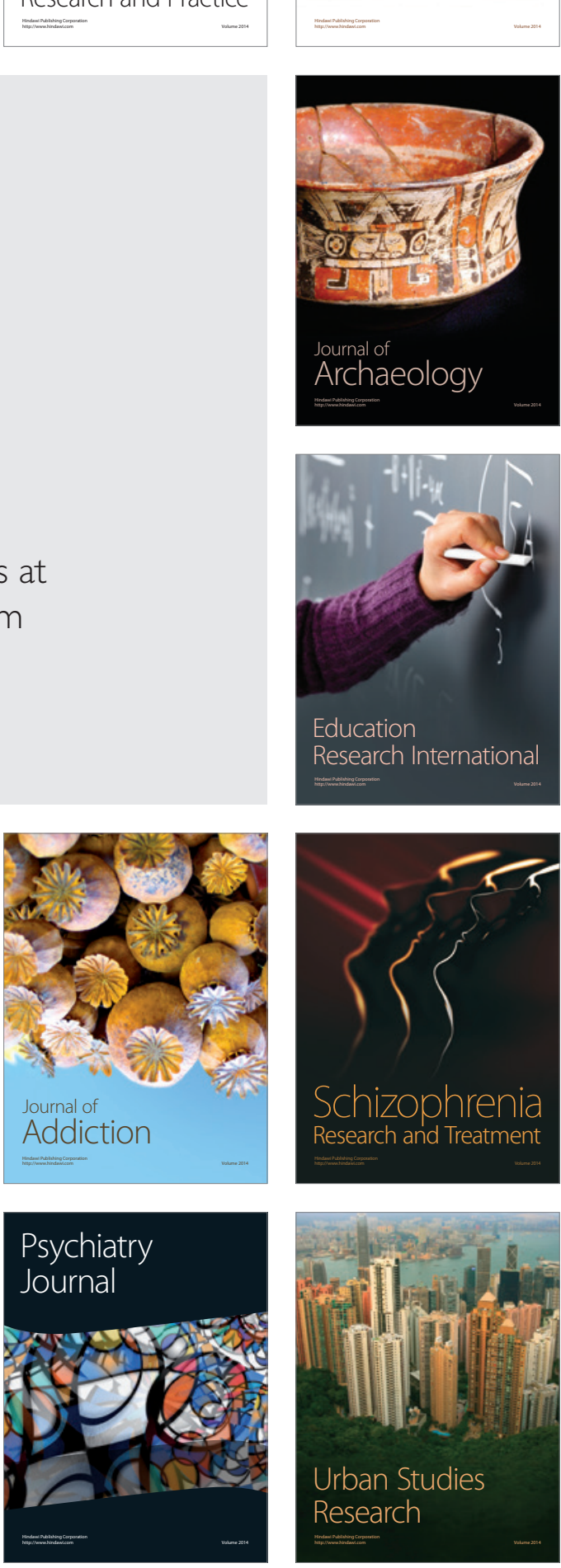